\title{
Anticancer Effects of Nutraceuticals in the Mediterranean Diet: An Epigenetic Diet Model
}

\author{
ROSA DIVELLA ${ }^{1}$, ANTONELLA DANIELE $^{1}$, EUFEMIA SAVINO $^{2}$ and ANGELO PARADISO ${ }^{1}$ \\ ${ }^{1}$ Institutional BioBank, Experimental Oncology and Biobank Management Unit, \\ IRCCS Istituto Tumori Giovanni Paolo II, Bari, Italy; \\ ${ }^{2}$ Clinical and Pathology Laboratory, IRCCS Istituto Tumori Giovanni Paolo II, Bari, Italy
}

\begin{abstract}
Epidemiological and clinical studies support the association between nutrition and development or progression of different malignancies such as colon, breast, and prostate cancer, defining these tumors as diet-associated cancer. The Mediterranean diet shows inverse associations with metabolic diseases, cardiovascular pathologies and various types of cancer. Many bioactive nutrients of the Mediterranean diet have been identified as factors protective against these types of pathologies. The epigenome has been identified as the primary goal of modulations in gene expression related to these molecular nutrients. In fact, they can modify the epigenome and can be incorporated into the 'epigenetic diet', which translates into a diet regimen that can be used therapeutically for health or preventative purposes. Most epigenetic changes are influenced by lifestyle and nutrition. Epigenetic therapy is a new area for the development of nutraceuticals whose absence of toxicity can represent a valid asset in cancer prevention strategies. Recent advances in understanding the mechanisms of nutrigenomics, nutrigenetics and nutraceuticals have led to the identification of superfoods capable of favorably conditioning gene expression. In this review, we highlight the importance of nutraceuticals present in the Mediterranean diet as epigenetic modifiers both in the mechanisms of tumor onset and as protective agents.
\end{abstract}

This article is freely accessible online.

Correspondence to: Rosa Divella, Institutional BioBank, Experimental Oncology and Biobank Management Unit, IRCCS Istituto Tumori Giovanni Paolo II, V. Le Orazio Flacco, 65, 70124, Bari, Italy. Tel: +39 805555259, e-mail: rosadive@inwind.it

Key Words: Mediterranean diet, epigenetic, nutraceuticals, nutrigenomics, cancer, review.
The Mediterranean diet constitutes a food model that characterizes not only a lifestyle, but also a culture, and has been indicated as a hub for improving health, quality of life and life span (1). Numerous studies have highlighted the positive correlation between the Mediterranean diet and longevity; individuals who adhere to a nutritional style like this have a longer life expectancy (2-4). Moreover, the Mediterranean diet prevents many metabolic, cardiovascular and neurodegenerative diseases, insulin resistance and different types of cancer (5-7). Today cancer represents the second leading cause of death in the world, immediately after cardiovascular diseases, but its onset curve has lowered in parallel with other chronic degenerative diseases, such as diabetes and obesity. In this context, diet plays a very important role. Epidemiological and clinical studies support the association between nutrition and development or progression of different cancer malignancies such as of the colon, breast, prostate and others, defining these tumors as diet-associated cancer (8-11). Over the years, many bioactive nutrients have been identified, on the one hand because they are involved in the development of tumors, on the other hand as protective factors. Among these are polyphenols, selenium, donors of methyl groups, retinoids, isothiocyanates and some allyl compounds $(12,13)$. These are molecules capable of intervening in the hepatic detoxification phases of type 1 and 2, DNA repair mechanisms, cell growth and differentiation, apoptosis, oxidative stress and in modulation of inflammation (14). However, in recent years, the epigenome has been identified as the primary goal of modulating gene expression related to these nutrients. The term 'epigenetic diet' has been introduced to indicate the consumption of foods such as soy, cruciferous vegetables and green tea, which influence epigenetic mechanisms capable of protecting against cancer and the aging process $(15,16)$. Proven bioactive nutritional factors are therefore able to modify the epigenome and can be incorporated into 
this epigenetic diet, which translates into a diet regimen that can be used therapeutically for health or preventative purposes $(17,18)$.

In this context, the Mediterranean diet as an epigenetic diet is characterized by a high consumption of whole grains (about $50-60 \%$ of the total caloric intake), and a high consumption of vegetables, fruit and legumes; use of extra virgin olive oil to cover about $70 \%$ of the lipid supply; regular consumption of fresh fish (especially blue fish); a regular but moderate consumption of red wine during main meals; with an optimal supply of omega- 3 both of animal and vegetable origin. This type of diet is associated with low mortality from all causes (19-21). For example, a high adherence to the Mediterranean diet is associated with a significant reduction in the risk of general mortality from cancer $(10 \%)$, with particular epidemiological relevance towards colorectal (14\%), prostate $(4 \%)$ and gastrointestinal tract $(56 \%)$ cancer (22-24). In 2003, the PREDIMED study confirmed that the Mediterranean diet, implemented with extra virgin olive oil or the consumption of three walnuts per day, was able to prevent cardiovascular disease (25). Between 2005 and 2010, the MOLI-SANI Study showed greater adherence to the Mediterranean diet to be associated with a reduction in leukocytes and platelets suggesting that the set of foods that make up the Mediterranean diet has antiinflammatory activity and a protective effect against many pathologies (primarily arteriosclerosis) with inflammatory pathogenesis (26). These and other studies demonstrate the existence of an inverse association between the Mediterranean diet and total mortality, incidence of coronary heart disease, thrombotic infarction and numerous neoplasms (27). Starting from this basis, the international scientific community has taken seriously the important role of the Mediterranean Diet, and the lifestyle it is inspired by, in increasing longevity and improving public health.

The Mediterranean diet can therefore be considered as a nutritional pool comprising various nutraceuticals, bioactive components present and carried by food, capable of favorably influencing health, both directly and through its own epigenetic mechanisms (Figure 1). The low animal protein content and the low glycemic index of the Mediterranean diet directly modulate the mammalian target of rapamycin (mTOR) pathway and the level of insulin-like growth factor1 (IGF1), known to be involved in the aging process and in longevity. In particular, the reduction of animal protein intake can significantly reduce the serum IGF1 level and inhibit mTOR activity with signal down-regulation that leads to the activation of forkhead box $\mathrm{O} 3$ (FOXO3A) and consequently to the transcription of homeostatic genes that promote longevity (28). Low-grade chronic inflammation due to poor nutrition in obesity, metabolic syndrome and diabetes mellitus 2 increases the risk of cancer and affects all its various stages, both by triggering the initial genetic mutation or epigenetic mechanism, and by promoting the onset of cancer and its progression and metastatic spread (29). Epidemiological studies have shown that the Mediterranean diet reduces the risk of the onset of various types of cancer. Bioactive nutrients in the Mediterranean diet not only modulate multiple interconnected processes involved in carcinogenesis, in the inflammatory response and in the production of free radicals, but also highlight the ability to promote the restoration of the inflammatory balance due to the maintenance of intestinal microbiota and the epigenetic modulation of oncogenetic and oncosuppressive factors (30-32).

In this review, we highlight the importance of nutraceuticals present in the Mediterranean diet as epigenetic modifiers both in the mechanisms of tumor onset and as protective agents.

\section{Nutraceuticals and Gene Expression}

Epigenetic therapy is a new area for the development of nutraceuticals whose absence of toxicity can represent a valid asset in the cancer prevention strategy. Recent advances in understanding the mechanisms of nutrigenomics, nutrigenetics and nutraceuticals have led to the identification of superfoods capable of favorably conditioning gene expression $(33,34)$. In the past, it was said, "you are what you eat". Today a new notion reflecting the interaction between genomic structure and nutrition is introduced: "eat correctly in relation to your genotype". However, the diet cannot always ensure an adequate supply of those nutrients and phyto derivatives able to actively condition gene expression, trying to optimize the positive aspects inherent in each individual's DNA and to limit the consequences of unfavorable genomic susceptibility. Thus, was born the concept of nutraceuticals, a mix of substances able to interact with the individual genotypic structure in function with the environmental one (phenotype) $(35,36)$. Nutraceuticals therefore take on the role of cellular and functional modulators, capable of ensuring the optimization of physiological processes (37). Most epigenetic changes are influenced by lifestyle and nutrition (38). Some nutraceuticals have emerged in the context of the scientific literature as a source of molecules capable of reversing epigenetic alterations and actively regulating gene and molecular expression, also preventing chronic degenerative diseases due to epigenetic modulation (39-41). Cancer, for example, represents a heterogeneous multi-stage disease, driven by progressive genetic and epigenetic anomalies. The epigenetic component is influenced by various exogenous and endogenous factors, including nutrition, the environment, ethnicity, lifestyle, medications, exposure to xenobiotics and toxins, physical activity, age, gender and family genetic heritage (42). Epigenetic therapy is a new 


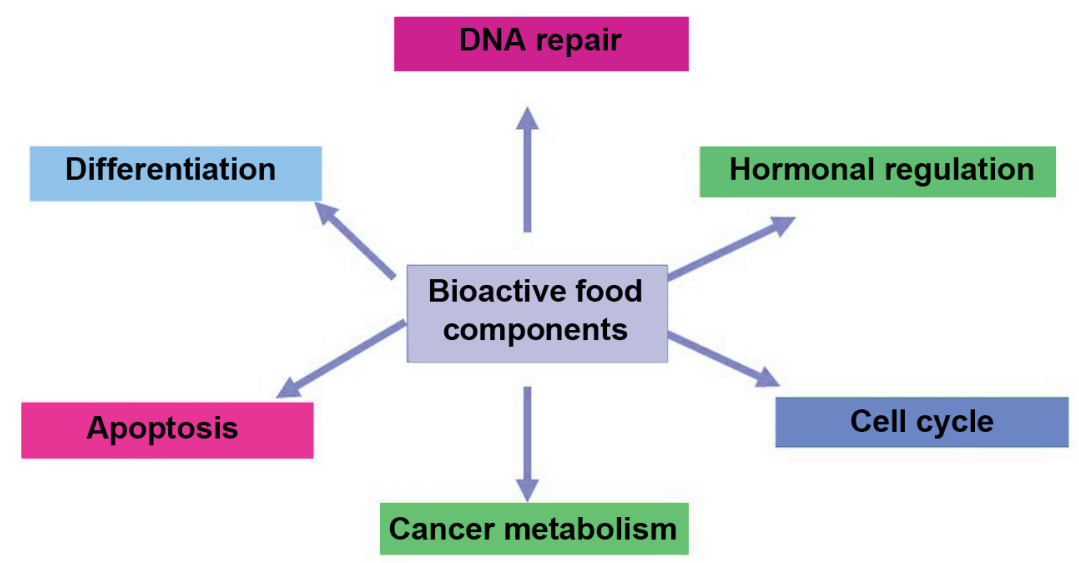

Figure 1. Diet may influence genetic and epigenetic events associated with several cancer process.

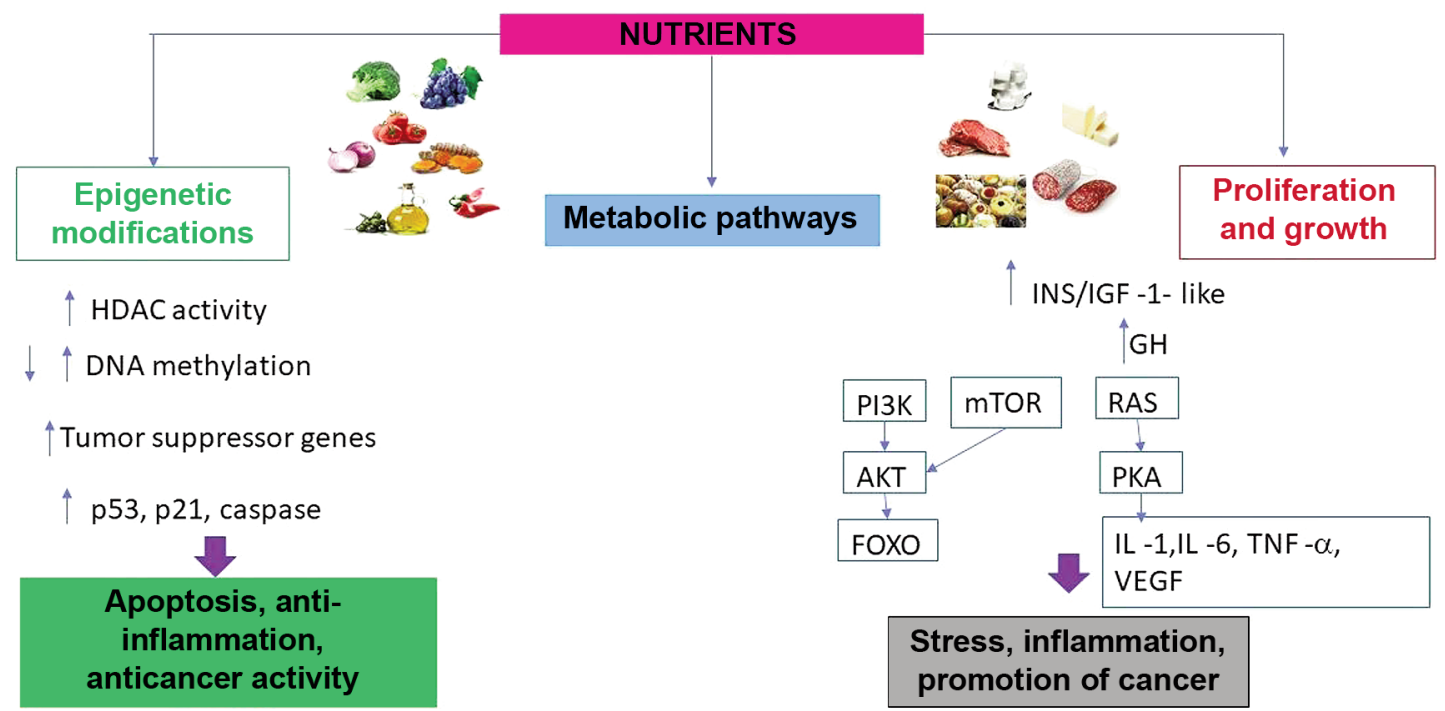

Figure 2. Different mechanisms of action induced by nutrients in the pathways of activation of protective mechanisms and promotion of tumor cell growth. HDAC: Histone deacetylases; p53: protein p53; p21: protein p21; INS/IGF: insulin/insulin-like growth factor; GH: growth hormone; RAS: rat sarcoma; mTOR mammalian target of rapamycin; PI3K phosphoinositide 3-kinases; AKT: protein-chinasi B; FOXO: forkhead box O; PKA: protein-chinasi A; VEGF: vascular endothelial growth factor; IL-1: interleukin -1, IL-6: interleukin-6; TNF - $\alpha$ : tumor necrosis alfa.

area for the development of nutraceuticals whose absence of toxicity can represent a valid asset in the cancer prevention strategy. Recent advances in understanding the mechanisms of nutrigenomics, nutrigenetics and nutraceuticals have led to the identification of superfoods capable of favorably conditioning gene expression (Figure 2) (43).

Curcuma longa. Curcuma longa is a perennial rhizomatous plant belonging to the Zingiberaceae family. The root is the component of greatest nutritional and phytotherapeutic interest. The use of the spice in herbal medicine requires the consumption of at least one tablespoon of turmeric per day, with the addition of a modest amount of pepper, which improves its absorption (44). Among the main constituents of the root of turmeric are the curcuminoids, of which the most represented is curcumin (45). Curcumin is a polyphenolic compound with anti-inflammatory, antioxidant and antilipidemic actions; its ability to modulate various pathologies has been recently demonstrated through modulation mechanisms and epigenetic regulation (46). In 
fact, numerous studies have shown its role as 'epigenetic inactivator' of key genes that regulate important pathologies such as neurodegenerative diseases and cancer (47-52). Epigenetic changes imply changes in DNA methylation, modifications of histones or microRNA expression patterns. These are mechanisms known to be interconnected with each other and for the key role they play in the progression of tumor, as well as in the failure of conventional chemotherapy (53). Taken together, the epigenetic mechanisms of the action of curcumin include (54-59):

- Inhibition of DNA methyltransferase (DNMT), a hypomethylating agent.

- Histone modification through regulation of both histone acetyltransferase (HAT) and histone deacetylase (HDAC).

- MircroRNA modulation (miR-15a, miR-16, miR-21-22-26).

- Activation of transcription factors, chemokines, cytokines, and tumor-suppressor genes.

Turmeric can be considered a molecule capable of interacting with numerous molecular targets involved in the inflammatory process. Its use in the oncology field has been shown to inhibit angiogenesis implicated in the development of tumor and its progression $(60,61)$. It is a potent inhibitor of nuclear factor kappa-light-chain-enhancer of activated Bcells (NF-kB), thus promoting a cell apoptotic response (62). Recent studies that have demonstrated the anticancer effects of turmeric have confirmed the beneficial effects of curcumin combined with various antineoplastic drugs in order to improve their clinical effects and reduce toxicity $(63,64)$. Curcumin can also exert an anticancer and chemopreventative activity on breast cancer. In this context, curcumin exerts its antitumor effect not only through its specific mechanisms of action already described, but also thanks to a complex molecular signaling network that involves the mechanisms underlying the cell proliferative processes, the receptors of estrogen (ER) and human epidermal growth factor receptor 2 (HER2) $(65,66)$.

Resveratrol. Resveratrol is another polyphenolic compound and is present in grapes, in wine, in some berries and oil seeds (peanuts), and in particular plants. In grapes, it is found only in the peel, while its content in wine depends on the vine plant, on the geographical location of the cultivation and on the fermentation time (67). Resveratrol is one of the phytoalexins naturally produced by numerous plants defending against pathogens such as bacteria and fungi. Resveratrol is capable of exerting a powerful antioxidant and anti-inflammatory action (68). Its role as a modulator of cell apoptosis is fundamental (69). The cellular apoptosis promoted by this stilbene, in fact, can be mediated by multiple mechanisms $(70,71)$ :

- Activation of mitochondria and caspase cascade.

- Up-regulation of cyclin dependent kinase inhibitors, apoptosis-inducing cytokines and related receptors.
- Down-regulation of cell survival proteins, such as survivin, B-cell lymphoma 2 (BCL2), B-cell lymphoma-extra large (BCL-XL).

- Inhibition of cell kinases that promote survival [mitogenactivated protein kinase (MAPK), phosphatidylinositol 3kinases (P13K), protein kinase $\mathrm{C}$ (PKC), epidermal growth factor receptor (EGFR) kinases] and factors that promote transcription, such as NF-kB, activator protein 1 (AP1) and early growth response protein 1 (EGR1).

Several studies have demonstrated the action of resveratrol in modulating DNA methylation in several genes involved in cancer (72). In a recent study, resveratrol was shown to restore the hypomethylated and hypermethylated state of key tumor-suppressor and oncogenic genes, respectively (73). In that study, methylation alterations were consistent with changes in mRNA expression. Therefore, the impact of resveratrol on the epigenetic methylation processes of breast cancer cells is significant and might allow potential new therapeutic targets for effective epigenetic therapy to be identified (74). In light of the above, resveratrol can be considered an epigenetic drug capable of exerting its anticancer activity by modifying the methylation status of genes related to various types of cancer and therefore represents a valid potential chemopreventative agent (75).

Lycopene. Lycopene is a natural antioxidant from the carotenoid family, present at high concentrations in ripe tomatoes and to a lesser extent in watermelon, apricot, grapes, pink grapefruit and papaya. The lycopene content in tomato is influenced by the ripening level; it has been calculated that $50 \mathrm{mg} / \mathrm{kg}$ of lycopene are present in ripe red tomatoes, while the concentration drops to $5 \mathrm{mg} / \mathrm{kg}$ in yellow varieties $(76,77)$. The bioavailability of the compound is higher in heat-treated products than in raw products thanks to the dissociation of the protein complexes in which it is incorporated and the dispersion of the crystalline aggregates of carotenoids (78). Several studies attribute the ability of lycopene to reduce prostate cancer risk to it modulating the expression of genes associated with inflammation, apoptosis and cancer progression (79). Carotenoids, as well as their metabolites and oxidation products, improve communication at the level of intercellular gap junctions, which are considered one of the cancer prevention mechanisms by playing a role in the regulation of cell growth, differentiation and apoptosis (80). Gap junction communication is in fact deficient in many forms of tumors and the restoration of this function is associated with a reduction in cell proliferation (81). Several studies have highlighted how lycopene has cytotoxic effects against different types of cancer $(82,83)$. It is commonly believed that a better understanding of the mechanisms underlying the anticancer effects of lycopene may provide new therapeutic targets for the treatment of cancer. In the case of prostate cancer, lycopene has been 
observed to regulate the expression of serine/threonine kinase 2 (AKT2) and to regulate the expression of miRNA $(84,85)$. In this context, an important role in the inhibition of prostate cancer progression would be precisely correlated with these epigenetic mechanisms.

Ellagic acid. Ellagic acid is a phenolic compound that can be extracted from pomegranate peel and which is present in many red fruits, such as raspberries, strawberries and cranberries, as well as in walnuts. It is also present in goji berries (86). The anti-angiogenic activity of ellagic acid is mediated by the abolition of the hypoxia gate at the $\mathrm{Pl} 3 \mathrm{~K} / \mathrm{AKT} / \mathrm{mTOR}$, MAPK and VEGF/VEGFR2 pathways, which involve the suppression of the response towards HDAC6 and hypoxia-inducible factor 1 subunit alpha (HIF1 $\alpha$ ) (87). Molecular studies have confirmed the interaction of ellagic acid with the kinases that regulate the conduction of angiogenic signaling $(88,89)$. Furthermore, ellagic acid was shown to reduce the expression of HDAC, thereby contributing to the inhibition of neovascularization processes (90). Ellagic acid is a natural anti-inflammatory and immunomodulating molecule; for example, it is able to modulate IL1 $\beta$, IL6, IL8, IL10, C-C motif chemokine ligand 2 (CCL2) and the expression of the TNFA gene in HaCaT cells, after their irradiation with UVB (91). Combination of ellagic acid and curcumin at various concentrations demonstrated better anticancer properties than did the individual molecules (92). Furthermore, both curcumin and ellagic acid have been shown to restore the expression and action of p53, an important promoter of apoptosis. Recent in vivo and in vitro studies revealed that ellagic acid has evident epigenetic actions: Anticancer effects; inhibition of the proliferation of cancer cells; induction of apoptosis; breakdown of DNA binding by carcinogens; antiinflammatory and antiangiogenic properties; reducing spread of metastases $(93,94)$.

Indole 3 carbinol (I3C), di-indoylmethane (DIM) and sulforaphane. DIM and its precursor, I3C, are active nutrients derived from cruciferous vegetables, broccoli, cabbage, Brussels sprouts and savoy cabbage (95). These are natural substances derived from the degradation of glucosinolate glucobrassicin. Recent studies indicated the strong synergistic action of the association of I3C with DIM. Glucoraphanin is a glucosinate that is found at high concentrations in broccoli and other members of the brassacea family. Sulforaphane is its active form, which is obtained when glucorafanin is metabolized by the enzyme myrosinase, which is freed from the leaves of brassicae when they are chewed $(96,97)$. Cooking partially denatures myrosinase, leaving glucorafanin partially intact, but the bioavailability in this case is, however, guaranteed by the intestinal microflora, which can produce myrosinase (98).
I3C induces the arrest of tumor cell growth in the G1 phase of the cell cycle. It is a potent inducer of cytochrome P450 enzymes, including CYP1A1, CYP1A2 and CYP1B1 (99). I3C and DIM modulate the metabolism of estrogens by increasing 2-hydroxylation, which leads to an increase in the 2-OH:16-OH ratio relative to the estrogen metabolites (100). In humans, these hormones are degraded into different metabolites, which can stimulate or inhibit the onset of a hormone-sensitive neoplasm $(101,102)$. The metabolites involved are estrone 2 (2OHE1), which tends to inhibit the growth of the neoplasm, and estrone 16 (16OHE1), which promotes tumor growth. Those who have a prevalence of estrone 2 are more protected than those who have a higher production of estrone 16 . When the $2-\mathrm{OH}: 16-\mathrm{OH}$ ratio is lower than unity, there are serious clinical implications, while when this ratio is higher than three, the consequences are more favorable (103). A metabolite of estradiol is $16-\alpha-$ hydroxyestrone which, owing to its covalent bond with its receptor, induces a persistent biological response, which consists of stimulating tumor mitogenic growth (104). Other conversion products for estrone and estradiol are 2hydroxylated estrogens, such as 2-hydroxyestrone and 2hydroxyestradiol. Unlike 16- $\alpha$-hydroxyestrone, these hydroxylated forms seem to inhibit mitogenic stimulation of neoplastic lesions, showing anticancer properties and target multiple aspects of cancer cell-cycle regulation and survival, including caspase activation, cyclin-dependent kinase activities, estrogen metabolism and estrogen receptor signaling (105-106). The positive effect that DIM and I3C have is related to the fact that they both modify the estradiol isoxylation receptor site, reducing the production of $16-\alpha-$ hydroxyestrone in favor of 2-hydroxyestrone. In addition, both I3C and DIM stimulate the liver production of detoxifying enzymes capable of neutralizing and degrading the harmful metabolites of both estrogens and xeno-estrogens taken up as environmental pollutants or in food (107). In experimental studies, the molecules have proven to be effective in reducing the growth of papillomavirus (108). They are also capable of stimulating the antitumor genes $p 21, p 27$ and p53 with nonspecific preventative effect and against herpes simplex and human papillomavirus (109, 110). Sulforaphane exhibits a well-known epigenetic action, being able to act for example as an inhibitor of HDAC, emerging as both a curative and preventive chemotherapy agent $(111,112)$. It has multiple effects including cell growth arrest, differentiation and apoptosis as recently demonstrated in the case of prostatic neoplasms $(113,114)$. Other benefits of sulforaphane come from its activities as an anticancer agent. For example, sporadic breast cancer is frequently associated with aberrant DNA methylation patterns that are reversible and sensitive to factors including diet (115). Sulforaphane affects the methylation and expression of tumor-suppressor genes phosphatase and tensin homolog 
$(P T E N)$ and retinoic acid receptor-B (RARB), as well as the expression of DNA methylation reaction regulators such as DNMT1, p53 and p21, silencing the tumor-suppressor genes in breast cancer cells, and representing a therapeutic opportunity to assist other conventional therapies $(116,117)$. Moreover, sulforaphane significantly inhibits the viability and proliferation of breast cancer cells in vitro, while it has negligible effects on normal cells. Telomerase inhibition has received considerable attention due to its high expression in tumor cells and its extremely low level of expression in normal cells (118). Sulforaphane treatment inhibits the catalytic subunit of human telomerase. Scientific studies have paralleled interferences in DNA methyltransferase activity, in particular DNMT1 and DNMT3A, which were found to decrease in breast cancer tumor cells treated with sulforaphane, suggesting how the latter may be able to repress telomerase through specific epigenetic precursors (119). Furthermore, the down-regulation of telomerase expression facilitates the induction of apoptosis of breast cancer neoplastic cells, opening a way for approaches aimed at sulforaphane-mediated prevention of this neoplasm. Diet is a known modifiable factor associated with the risk of several cancer types, especially breast cancer. The role of bioactive compounds of food origin, including those found in cruciferous vegetables, is an active field of research in terms of cancer chemoprevention (120-122). DIM, the main bioactive indole of cruciferous plants, has shown chemopreventative activity in all stages of breast cancer carcinogenesis. Oral intake of DIM has been associated with an increase in BRCAl mRNA expression in women with an unfavorable BRCA1 mutation (123). The possibility of mitigating the effect of this hereditary mutation, increasing the physiological expression of the gene and thus normalizing the levels of DNA-repairing proteins, represents a clinically important additional tool in the prevention strategies available to women at high breast and ovarian cancer risk.

The epithelial-mesenchymal transition (EMT) plays a key role in tumor progression. The cells in EMT up-regulate the expression of proteins related to cell motility and show a greater propensity for migration and metastasis (124). Therefore, the prevention of EMT is an important tool for the inhibition of tumor metastases. Food phytoestrogens found in cruciferous vegetables are known to have biological efficacy including chemopreventative activity against tumors (125). In particular, it has been observed in tumor cell lines that DIM can induce not only antiproliferative action, apoptosis and cell-cycle arrest, but also anti-metastatic activity due to its ability to inhibit EMT, as well as associated processes (NOTCH1 and TGF $\beta$ ) (126). A diet rich in fruit and vegetables provides phytochemicals such as I3C, sulforaphane and DIM, which may be jointly responsible for the prevention of many types of cancer, including hormone- dependent neoplasms such as those of the breast, ovary, uterus and prostate $(127,128)$. Attention should be paid to bioavailability, which is related to the cooking and storage methods. Both the cooking temperature and preservation even at $4^{\circ} \mathrm{C}$ can significantly alter the quantity of active components in foods containing these substances, compromising their efficacy of therapeutic action (129). In conclusion, glucosinolates present in cruciferous vegetables such as broccoli, cabbage, Brussels sprouts and cauliflower have beneficial effects on general health as potential antineoplastic effects due to their role in preventing the initial processes of carcinogenesis. This occurs, in particular, thanks to the induction of both anti-oxidant and detoxifying defense mechanisms and epigenetic mechanisms underlying them, including the modification of cytosine-phosphate-guanine $(\mathrm{CpG})$ methylation, which occurs mainly in cancer-related genes, and the regulation of histone modification and changes in the expression of the miRNA (130).

Silybum marianum. The milk thistle $S$. marianum is a biennial herbaceous plant of the Asteraceae family. The main phytochemical components to which its action and its therapeutic potential might be attributed go under the generic name of flavolignans (131). Its peculiar phytocomplex includes various active components such as:

- Silandrin, which interferes in the biosynthesis of triglycerides and the activity of cyclo-oxygenase, which show antioxidant activity (132).

- Silymarin, which modulates the action of liver enzymes capable of inactivating and eliminating pharmacological molecules, alcohol, and xenobiotics (133).

- Silibinin, which inhibits the biosynthesis of leukotrienes by acting on the inflammatory process and also shows antioxidant action (134).

Their generic action therefore is to stimulate the cellular elimination of toxins and the reduction of the inflammatory component (135). The most important flavonoid fraction is given by silymarin, which is a group of flavonoids characterized by an antioxidant and regenerative activity with a marked tropism towards hepatocytes (136). They have an anabolic action on the metabolic function of these cells and promote regeneration. In clinical practice, S. marianum is used in the treatment of liver diseases of any nature in which anatomo-functional damage has resulted. It exerts a regenerative action on hepatocytes making them more resistant to hepatotoxic agents (137). The damage caused by free radicals to cellular structures such as membranes causes a great release by lipolysis of fatty acids of the omega 6 series, such as arachidonic acid. This leads to an increase in the synthesis of the main inflammatory mediators, leukotrienes, produced by a reaction catalyzed by lipoxygenase (138). Silymarin acts as a powerful inhibitor of this enzyme thereby stopping the pathological decomposition 
of membrane lipids and consequently the synthesis of prostaglandins during the inflammatory process. Silibinin exerts a strong antiproliferative, anti-inflammatory and proapoptotic action $(139,140)$. Numerous studies have shown experimentally that through an epigenetic mechanism it inhibits the development of tumors induced in the liver, prostate, skin, colon and recently also in the breast, also promoting the inhibition of the proliferation of tumor cell lines in vitro by exercising anti-metastatic action (141-144). Furthermore, silymarin has found a role as a new therapy for the treatment of cancer in lung, colon, skin, prostate, breast, bladder and liver tumors, regulating neoplastic cells in the various stages of growth and proliferation, and influencing fundamental epigenetic and nutrigenomic processes, such as apoptosis and angiogenesis (145). Its synergistic combination with curcumin, quercetin, soy isoflavones and epigallocatechin3-gallate (EGCG) is excellent in chemoprevention of aerodigestive and GI cancer (146).

Capsaicin. Capsaicin is a chemical compound present in different concentrations in plants of the Capsicum genus (e.g. in spicy chili), which gives them their characteristic irritating power. Chili pepper is the main source of capsaicinoids in nature, which consist of capsaicin, di-hydrocapsaicin, nor-dihydrocapsaicna, homo-di-hydrocasaicin and homo-capsaicin which are capable of exerting multiple pharmacological and physiological effects (147). Therefore, capsaicinoids might be used in the clinic to relieve pain, prevent cancer and lose weight (148). Capsaicin manifests anticancer activity through delicate molecular epigenetic mechanisms. On the one hand it facilitates apoptosis and on the other it inhibits the expression of VEGF responsible for the vascularization of the tumor mass, the angiogenic process that feeds it and its metastases $(149,150)$. In addition, capsaicin has been reported to preferentially inhibit the activity of tumorassociated NADH oxidase, which belongs to a family of hydroquinone oxidases implicated in the development and growth of cancer (151). Capsaicin exhibits antiproliferative actions on prostate cancer cells by inducing apoptosis. It reduces the expression of the androgenic receptor, inhibits the activity of the proteasome which suppresses the degradation of inhibitor of nuclear factor kappa B ( IkB $\alpha$ ), thereby preventing the activation of NF-kB (152). Such actions might play a role in the treatment of prostate cancer, even hormone-independent. The NF-kB signaling pathway is in fact constitutively activated in hormone-independent carcinomas $(153,154)$.

Quercetin. Quercetin is a flavonol and is the aglyconic component of various glycosides including rutin and quercetrin. In foods it is found mainly in capers, in some vegetables such as red onion, cruciferous vegetables, celery, lettuce, asparagus, tomatoes and shallots $(155,156)$.
Quercetin is also found in some fruits, such as berries, pomegranate, black uva and therefore also in red wine, citrus fruits, apples, nuts, pistachios, in green tea in propolis. The biosynthesis of quercetin is stimulated by light so that the compound accumulates mainly in the leaves and peel of fruit. A diet rich in vegetables and fruit with peel provides an intake of 200 to $500 \mathrm{mg}$ per day of quercetin (157). The compound has antioxidant, anti-inflammatory, antiallergic, anti-aggregant and anti-thrombotic actions and has cardioprotective effects (158). The antioxidant activity is due to the reactivity of its phenolic group. There are several epigenetic mechanisms associated with quercetin such as the suppression of Janus kinase 2 (JAK2) capable of inhibiting the proliferation, invasion and migration of cancer cells with an associated effective stimulus towards the mechanisms of autophagy and apoptosis to promote the death of cancer cells (159). In vitro actions on cellular signaling pathways and anticancer effects have been detected. The actions of quercetin on signal pathways can be reproduced both with the use of food sources (simple onion soup) and with the contribution of dietary supplements (160). One of the main forms of quercetin present in the diet is quercetin-4glucoside. This conjugate form occurs at high levels in onions and is preferentially absorbed in the intestine (161). Quercetin is eliminated rapidly (half-life of approximately 2 hours) and is present in the urine in conjugated form (162). Cell-culture studies show that the flavones quercetin and kaempferol inhibit inducible nitric oxide synthase, cyclooxygenase-2, and C-reactive protein (163). The inhibition of inflammatory factors is accomplished through the inhibition of the transcription factor NF-kB (164). The anti-inflammatory and antioxidant actions may be responsible for the favorable effects observed in patients with chronic prostatitis and interstitial cystitis (165). Quercetin inhibits the expression and function of the androgenic receptor in $\mathrm{LNCaP}$ prostate cancer cells and reduces regulation of androgen-inducible genes including PSA, and ornithine decarboxylase which play a role in tumor development and progression (166). Quercetin causes a decrease in IGF1 levels and an increase in IGFBP3 which is associated with an increase in pro-apoptotic protein and a decrease in anti-apoptotic proteins BCL2 and BCL-XL (167). Quercetin reduces HER2/neu protein level and inhibits the PI3K/AKT signaling pathway (168). Since activation is necessary for cell survival, its inhibition contributes to apoptosis (169). Quercetin activates caspase-3 and -9 and releases cytochrome $\mathrm{c}$ in leukemic cells. It blocks the $\mathrm{G}_{1}$ cell-cycle progression in numerous tumor cell lines, demonstrating antiproliferative effects (170). Quercetin significantly inhibited the growth of aggressive (PC3) and moderately aggressive (DU-145) prostate cancer cell lines, demonstrating that its effects are correlated with tumor aggression and that the mechanism of actions passes through 
the hyper-regulation of tumor-suppressor genes and the decrease in regulation of oncogenes and cell cyclecontrolling genes (171).

Fisetin. Fisetin is a flavonol found in various vegetables and some fruits, including strawberries, apples, persimmons, onions and cucumbers (172). Fisetin has been shown to inhibit or delay the growth of various cancer cells both in culture and in vivo. Its targets of action are multiple intracellular signaling pathways including cellular survival and apoptosis regulatory mechanisms, angiogenic and metastatic switches going upstream to modulate a distinct series of kinase transcription factors and their regulation modalities (173-175). Current scientific evidence supports the hypothesis that fisetin is a promising agent for the treatment of cancer and its epigenetic prevention (176). One of the epigenetic modulation pathways that characterizes the activity of fisetin is the inhibition of the mTOR and $\mathrm{PI} 3 \mathrm{~K} / \mathrm{AKT}$ cascade, which is at the center of many studies concerning the mechanisms underlying the development and proliferation of neoplastic cells (177-179).

Epigallocatechin-3-gallate. EGCG is a type of catechin which is especially abundant in green tea (180). It is a polyphenol with anti-inflammatory and antioxidant activity and can be found in other foods such as apples, blackberries, raspberries, walnuts and hazelnuts, pistachios, plums, peaches and avocados (181). Green tea catechins are able to reverse DNA methylation at the level of tumor-suppressor genes and increase their transcription (182). In vivo studies have shown that compared to a placebo group, high consumption of green tea, and therefore a high intake of EGCG, was able to reduce the methylation of caudal type homeobox $2(C D X 2)$ and bone morphogenetic protein 2 $(B M P 2)$ in gastric cancer, with effective epigenetic modulation (183). The polyphenols of green tea, including EGCG, are also able to mediate the epigenetic induction of metalloprotease inhibitors (TIMP), including TIMP3, whose levels play a key role in suppressing the invasiveness and gelatinolytic activity of MMP2 and MMP9, enzymatic activities promoting the metastatic process $(184,185)$.

Anthocyanins. Anthocyanins are among the most important groups of pigments found in vegetables, although they are found mainly in fruit. The richest sources of anthocyanins are berries, black grapes, aubergines, red beet, mallow, cherries, apples, cruciferous vegetables, citrus fruits and pomegranate. The more intense their coloring (reddish or bluish), the greater the precious anthocyanin content (186). Diets rich in fruits and vegetables are known to be associated with a lower risk of developing cancer (187). Drawing on these observations, there is a strong interest in isolating and characterizing the nutritive and non-nutritive components of fruits and vegetables as potential chemopreventative agents $(188,189)$. In this context, isothiocyanates and anthocyanins, which are present in consumer vegetables, are two of the most important agents, especially thanks to their preventive efficacy both in vitro and in experimental models (190). At an epigenetic level, anthocyanins influence the cell cycle, allowing a better efficacy of the activation of DNA-repair mechanisms $(191,192)$.

The polyphenols of extra virgin olive oil. Extra virgin olive oil is obtained through a technological process that allows the preservation of compounds present in the olives which otherwise would be lost during the refining/rectification phases, as happens in the production of other vegetable oils (193). Extra virgin olive oil is composed of monounsaturated fatty acids (oleic acid) and omega-3. There is also a small percentage of saturated fats, linoleic acid and vitamin E. It is characterized by the presence of phenolic acids and alkalis, secoiridoids, flavonoids, lignans and hydroxy-isochromans (194). The phenolic fraction has the greatest protective action against oxidative processes and is responsible for shelf life of the product. The consumption of extra virgin olive oil is correlated with the low incidence of arteriosclerosis, diabetes, inflammatory and autoimmune diseases, skin diseases and aging, and tumor pathology (195). Laboratory experiments have shown that oleic acid, a powerful antioxidant, facilitates the repair of DNA damaged by excessive exposure to the sun. Oleic acid also exhibits favorable actions on the cardiovascular system (196). The polyphenol oleocantal, responsible for the pungent taste sensation of olive oil, has inhibitory actions on cyclooxygenases, so that the continuous consumption of olive oil may have preventative actions on inflammatory pathologies in a similar way to compounds such as ibuprofen (197). In the tumor field, polyphenols isolated from extra virgin olive oil inhibit the expression of the HER2/neu protein (ERBB2), expression of which is correlated with aggressive breast carcinoma (198). Olive oil also enhances the inhibitory effects on tumor growth of the monoclonal antibody to HER2, trastuzumab (Herceptin ${ }^{\mathrm{TM}}$ ), in breast cancer (199).

\section{Conclusion}

Several bioactive components of the Mediterranean diet are of particular interest in the field of epigenetics. For many of these compounds, their anticancer properties have been highlighted and they can play an active role particularly in the prevention of cancer. Numerous studies suggest that a number of nutritional compounds have epigenetic targets on cancer cells, in both their formation and in their development and proliferation. It follows that today we can speak in all respects of an 'epigenetic diet aimed at the integration of nutraceuticals capable of activating epigenetic modulation. However, in recent years, the epigenome has been identified 
as the primary goal of modulating gene expression related to these molecular nutrients. The latter can widely modulate epigenetic mechanisms that lead to a rapid and effective regulation of gene expression, precisely in response to nutritional changes. Considerable progress can be made with nutrigenomics and knowledge of the genome of plants which will allow the identification and selection of protective foods with more accuracy. In the near future, it will be possible to arrive at a sort of nutriprevention and nutritherapy based on the knowledge of the genome of individuals at risk or suffering from pathological events. The Mediterranean diet rich in fruit and vegetables and citrus fruits, cruciferous vegetables supplemented with food and phytotherapeutic compounds is probably the way forward for future studies.

\section{Conflicts of Interest}

No conflict of interest to declare.

\section{Authors' Contributions}

Divella Rosa: Article writing. Daniele Antonella: References. Savino Eufemia: English language revision. Paradiso Angelo: Responsible for the BIOMIS project.

\section{Acknowledgements}

The study was funded by PON MIUR 2014-2020 Biomis Ca.Re.Bios.

\section{References}

1 Poli A, Agostoni C, Graffigna G, Bosio C, Donini LM and Marangoni F: The complex relationship between diet, quality of life and life expectancy: A narrative review of potential determinants based on data from Italy. Eat Weight Disord 24(3): 411-419, 2019 PMID: 30264391. DOI: 10.1007/s40519-0180582-2

2 Tripp ML, Dahlberg CJ, Eliason S, Lamb JJ, Ou JJ, Gao W, Bhandari J, Graham D, Dudleenamjil E and Babish JG: A lowglycemic, Mediterranean diet and lifestyle modification program with targeted nutraceuticals reduces body weight, improves cardiometabolic variables and longevity biomarkers in overweight subjects: A 13-week observational trial. J Med Food 22(5): 479489, 2019. PMID: 31084538. DOI: 10.1089/jmf.2018.0063

3 Pavlidou E, Mantzorou M, Fasoulas A, Tryfonos C, Petridis D and Giaginis C: Wine: An aspiring agent in promoting longevity and preventing chronic diseases. Diseases 6(3): pii: E73, 2018 PMID: 30096779. DOI: 10.3390/diseases6030073

4 Foscolou A, Magriplis E, Tyrovolas S, Soulis G, Bountziouka V, Mariolis A, Piscopo S, Valacchi G, Anastasiou F, Gotsis E, Metallinos G, Tyrovola D, Polystipioti A, Polychronopoulos E, Matalas AL, Lionis C, Zeimbekis A, Tur JA, Sidossis LS, Panagiotakos D; MEDIS Study Group: Lifestyle determinants of healthy ageing in a Mediterranean population: The multinational MEDIS study. Exp Gerontol 110: 35-41, 2018. PMID: 29763722. DOI: 10.1016/j.exger.2018.05.008
5 Pan B, Wu Y, Yang Q, Ge L, Gao C, Xun Y, Tian J and Ding G: The impact of major dietary patterns on glycemic control, cardiovascular risk factors, and weight loss in patients with type 2 diabetes: A network meta-analysis. J Evid Based Med 12(1): 29-39, 2019. PMID: 30070019. DOI: 10.1111/jebm.12312

6 Akgüllü Ç, Sırıken F, Eryılmaz U, Akdeniz M, Ömürlü İK, Pekcan G, Güngör H, Kurtoğlu T: The relation between compliance to the Mediterranean diet and the extensiveness of coronary artery disease. Turk Kardiyol Dern Ars 43(4): 340349, 2015. PMID: 26142787. DOI: 10.5543/tkda.2015.49321

7 Jafari Nasab S, Bahrami A, Rafiee P, Hekmatdoust A, Ghanavati M, Rashidkhani B, Sadeghi A, Asadzadeh Aghdaei H, Naja F and Hejazi E: Healthy Eating Index-2010 and Mediterranean-Style Dietary Pattern Score and the risk of colorectal cancer and adenoma: A case-control study. Nutr Cancer 5: 1-10, 2019. PMID: 31687849. DOI: 10.1080/01635581.2019.1683212

8 Laudisio D, Barrea L, Muscogiuri G, Annunziata G, Colao A and Savastano S: Breast cancer prevention in premenopausal women: Role of the Mediterranean diet and its components. Nutr Res Rev 1: 1-14, 2019. PMID: 31571551. DOI: 10.1017/S0954422419000167

9 Aran V, Victorino AP, Thuler LC and Ferreira CG: Colorectal cancer: Epidemiology, disease mechanisms and interventions to reduce onset and mortality. Clin Colorectal Cancer 15(3): 195203, 2016. PMID: 26964802. DOI: 10.1016/j.clcc.2016.02.008

10 Deng FE, Shivappa N, Tang Y, Mann JR and Hebert JR: Association between diet-related inflammation, all-cause, allcancer, and cardiovascular disease mortality, with special focus on prediabetics: Findings from NHANES III: Eur J Nutr 56(3): 10851093, 2017. PMID: 26825592. DOI: 10.1007/s00394-016-1158-4

11 Vikram A and Jena G: Diet-induced hyperinsulinemia accelerates growth of androgen-independent PC-3 cells in vitro. Nutr Cancer 64(1): 121-127, 2012. PMID: 22171530. DOI: $10.1080 / 01635581.2012 .630556$

12 Li Y, Li S, Meng X, Gan RY, Zhang JJ and Li HB: Dietary natural products for prevention and treatment of breast cancer. Nutrients 9(7) pii: E728, 2017. PMID: 28698459. DOI: 10.3390/nu9070728

13 Rescigno T, Micolucci L, Tecce MF and Capasso A: Bioactive nutrients and nutrigenomics in age-related diseases. Molecules 22(1) pii: E105, 2017. PMID: 28075340. DOI: 10.3390/ molecules22010105

14 Efferth T, Saeed MEM, Mirghani E, Alim A, Yassin Z, Saeed E, Khalid HE and Daak S: Integration of phytochemicals and phytotherapy into cancer precision medicine. Oncotarget $8(30)$ : 50284-50304, 2017. PMID: 28514737. DOI: 10.18632/ oncotarget.17466

15 Sapienza C and Issa JP: Diet, nutrition, and cancer epigenetics. Annu Rev Nutr 36: 665-681, 2016. PMID: 27022771. DOI: 10.1146/annurev-nutr-121415-112634

16 Andreescu N, Puiu M and Niculescu M: Effects of dietary nutrients on epigenetic changes in cancer. Methods Mol Biol 1856: 121-139, 2018. PMID: 30178249. DOI: 10.1007/978-14939-8751-1_7

17 Cheng Z, Zheng L and Almeida FA: Epigenetic reprogramming in metabolic disorders: nutritional factors and beyond. J Nutr Biochem 54: 1-10, 2018. PMID: 29154162. DOI: 10.1016/ j.jnutbio.2017.10.004

18 Steiger $\mathrm{H}$ and Thaler L: Eating disorders, gene-environment interactions and the epigenome: Roles of stress exposures and 
nutritional status. Physiol Behav 162: 181-185, 2016. PMID: 26836275. DOI: 10.1016/j.physbeh.2016.01.041

19 Georgia-Eirini D, Athina S, Wim VB, Christos K and Theodoros C: Natural products from Mediterranean diet: from anti-hyperlipidemic agents to dietary epigenetic modulators. Curr Pharm Biotechnol 20(10): 825-844, 2019. PMID: 31264546. DOI:10.2174/1573407215666190628150921

20 Carruba G, Cocciadiferro L, Di Cristina A, Granata OM, Dolcemascolo C, Campisi I, Zarcone M, Cinquegrani M and Traina A: Nutrition, aging and cancer: lessons from dietary intervention studies. Immun Ageing 13: 13, 2016. PMID: 27057203. DOI:10.1186/s12979-016-0069-9

21 Ostan R, Lanzarini C, Pini E, Scurti M, Vianello D, Bertarelli C, Fabbri C, Izzi M, Palmas G, Biondi F, Martucci M, Bellavista E, Salvioli S, Capri M, Franceschi C and Santoro A: Inflammaging and cancer: A challenge for the Mediterranean diet. Nutrients 7(4): 2589-2621, 2015. PMID: 25859884. DOI: $10.3390 /$ nu7042589

22 Capurso C and Vendemiale G: The Mediterranean diet reduces the risk and mortality of the prostate cancer: A narrative review. Front Nutr 4: 38, 2017. PMID: 28884114. DOI: 10.3389/ fnut.2017.00038

23 Farinetti A, Zurlo V, Manenti A, Coppi F and Mattioli AV: Mediterranean diet and colorectal cancer: A systematic review. Nutrition 43-44: 83-88, 2017. PMID: 28935150. DOI: 10.1016/j.nut.2017.06.008

24 Schwingshackl L and Hoffmann G: Adherence to Mediterranean diet and risk of cancer: An updated systematic review and metaanalysis of observational studies. Cancer Med 4(12): 1933-1947, 2015. PMID: 26471010. DOI: $10.1002 / \mathrm{cam} 4.539$

25 Estruch R, Ros E, Salas-Salvadó J, Covas MI, Corella D, Arós F, Gómez-Gracia E, Ruiz-Gutiérrez V, Fiol M, Lapetra J, Lamuela-Raventos RM, Serra-Majem L, Pintó X, Basora J, Muñoz MA, Sorlí JV, Martínez JA, Fitó M, Gea A, Hernán MA, Martínez-González MA; PREDIMED Study Investigators: Primary prevention of cardiovascular disease with a Mediterranean diet supplemented with extra-virgin olive oil or nuts. N Engl J Med 378(25): e34, 2018. PMID: 29897866. DOI: 10.1056/NEJMoa1800389

26 Bonaccio M, Pounis G, Cerletti C, Donati MB, Iacoviello L, de Gaetano G; MOLI-SANI Study Investigators: Mediterranean diet, dietary polyphenols and low-grade inflammation: Results from the MOLI-SANI study. Br J Clin Pharmacol 83(1): 107113, 2017. PMID: 26935858. DOI: 10.1111/bcp.12924

27 Couto E, Boffetta P, Lagiou P, Ferrari P, Buckland G, Overvad K, Dahm CC, Tjønneland A, Olsen A, Clavel-Chapelon F, Boutron-Ruault MC, Cottet V, Trichopoulos D, Naska A, Benetou V, Kaaks R, Rohrmann S, Boeing H, von Ruesten A, Panico S, Pala V, Vineis P, Palli D, Tumino R, May A, Peeters PH, Bueno-de-Mesquita HB, Büchner FL, Lund E, Skeie G, Engeset D, Gonzalez CA, Navarro C, Rodríguez L, Sánchez MJ, Amiano P, Barricarte A, Hallmans G, Johansson I, Manjer J, Wirfärt E, Allen NE, Crowe F, Khaw KT, Wareham N, Moskal A, Slimani N, Jenab M, Romaguera D, Mouw T, Norat T, Riboli E and Trichopoulou A: Mediterranean dietary pattern and cancer risk in the EPIC cohort. Br J Cancer 104(9): 1493-1499, 2011. PMID: 21468044. DOI: 10.1038/ bjc. 2011.106

28 Vasto S, Buscemi S, Barera A, Di Carlo M, Accardi G and Caruso C: Mediterranean diet and healthy ageing: A Sicilian perspective. Gerontology 60(6): 508-518, 2014. PMID: 25170545. DOI: $10.1159 / 000363060$

29 Ostan R, Lanzarini C, Pini E, Scurti M, Vianello D, Bertarelli C, Fabbri C, Izzi M, Palmas G, Biondi F, Martucci M, Bellavista E, Salvioli S, Capri M, Franceschi C and Santoro A: Inflammaging and cancer: A challenge for the Mediterranean diet. Nutrients 7(4): 2589-2621, 2015. PMID: 25859884. DOI: 10.3390/nu7042589

30 Visioli F, Grande S, Bogani P and Galli C: The role of antioxidants in the Mediterranean diets: Focus on cancer. Eur J Cancer Prev 13(4): 337-343, 2004. PMID: 15554562.

31 Leri M, Scuto M, Ontario ML, Calabrese V, Calabrese EJ, Bucciantini $M$ and Stefani M: Healthy effects of plant polyphenols: Molecular mechanisms. Int J Mol Sci 21(4) pii: E1250, 2020. PMID: 32070025. DOI: 10.3390/ijms21041250

32 Carlos-Reyes Á, López-González JS, Meneses-Flores M, GallardoRincón D, Ruíz-García E, Marchat LA, Astudillo-de la Vega H, Hernández de la Cruz ON, López-Camarillo C: Dietary compounds as epigenetic modulating agents in cancer. Front Genet 10: 79, 2019. PMID: 30881375. DOI: 10.3389/fgene.2019.00079

33 Mazzone R, Zwergel C, Mai A and Valente S: Epi-drugs in combination with immunotherapy: A new avenue to improve anticancer efficacy. Clin Epigenetics 9: 59, 2017. PMID: 28572863. DOI: 10.1186/s13148-017-0358-y

34 Raynal NJ, Da Costa EM, Lee JT, Gharibyan V, Ahmed S, Zhang H, Sato T, Malouf GG and Issa JJ: Repositioning FDAapproved drugs in combination with epigenetic drugs to reprogram colon cancer epigenome. Mol Cancer Ther 16(2): 397-407, 2017. PMID: 27980103. DOI: 10.1158/15357163.MCT-16-0588

35 Aronson JK: Defining 'nutraceuticals': neither nutritious nor pharmaceutical. Br J Clin Pharmacol 83(1): 8-19, 2017. PMID: 26991455. DOI: 10.1111/bcp.12935

36 Durazzo A, Lucarini M and Santini A: Nutraceuticals in human health. Foods 9(3) pii: E370, 2020. PMID: 32209968. DOI: $10.3390 /$ foods 9030370

37 McCubrey JA, Lertpiriyapong K, Steelman LS, Abrams SL, Yang LV, Murata RM, Rosalen PL, Scalisi A, Neri LM, Cocco L, Ratti S, Martelli AM, Laidler P, Dulińska-Litewka J, Rakus D, Gizak A, Lombardi P, Nicoletti F, Candido S, Libra M, Montalto G and Cervello M: Effects of resveratrol, curcumin, berberine and other nutraceuticals on aging, cancer development, cancer stem cells and microRNAs. Aging (Albany NY) 9(6): 1477-1536, 2017. PMID: 28611316. DOI: 10.18632/aging.101250

38 Abdul QA, Yu BP, Chung HY, Jung HA and Choi JS: Epigenetic modifications of gene expression by lifestyle and environment. Arch Pharm Res 40(11): 1219-1237, 2017. PMID: 29043603. DOI: 10.1007/s12272-017-0973-3

39 Ikram M, Saeed K, Khan A, Muhammad T, Khan MS, Jo MG, Rehman SU and Kim MO: Natural dietary supplementation of curcumin protects mice brains against ethanol-induced oxidative stress-mediated neurodegeneration and memory impairment via NRF2/TLR4/RAGE signaling. Nutrients 11(5) pii: E1082, 2019. PMID: 31096703. DOI: 10.3390/nu11051082

40 Farhan M, Ullah MF, Faisal M, Farooqi AA, Sabitaliyevich UY, Biersack B and Ahmad A: Differential methylation and acetylation as the epigenetic basis of resveratrol's anticancer activity. Medicines 13: 6(1). pii: E24, 2019. PMID: 30781847. DOI: $10.3390 /$ medicines6010024 
41 Sanchita, Trivedi R, Asif MH and Trivedi PK: Dietary plant miRNAs as an augmented therapy: Cross-kingdom gene regulation. RNA Biol 15(12): 1433-1439, 2018. PMID: 30474479. DOI: 10.1080/15476286.2018.1551693

42 Romani M, Pistillo MP and Banelli B: Environmental epigenetics: Crossroad between public health, lifestyle, and cancer prevention. Biomed Res Int 2015: 587983, 2015. PMID: 26339624. DOI: $10.1155 / 2015 / 587983$

43 Kelly $\mathrm{AD}$ and Issa JJ: The promise of epigenetic therapy: Reprogramming the cancer epigenome. Curr Opin Genet Dev 42: 68-77, 2017. PMID: 28412585. DOI: 10.1016/j.gde.2017.03.015

44 Patil VM, Das S and Balasubramanian K: Quantum chemical and docking insights into bioavailability enhancement of curcumin by piperine in pepper. J Phys Chem A 120(20): 3643 3653, 2016. PMID: 27111639. DOI: 10.1021/acs.jpca.6b01434

45 Ali Z, Saleem M, Atta BM, Khan SS and Hammad G: Determination of curcuminoid content in turmeric using fluorescence spectroscopy. Spectrochim Acta A Mol Biomol Spectrosc 213: 192-198, 2019. PMID: 30685558. DOI: 10.1016/j.saa.2019.01.028

46 Hewlings SJ and Kalman DS: Curcumin: A review of its effects on human health. Foods 6(10) pii: E92, 2017. PMID: 29065496. DOI: 10.3390/foods6100092

47 Wan Mohd Tajuddin WNB, Lajis NH, Abas F, Othman I and Naidu R: Mechanistic understanding of curcumin's therapeutic effects in lung cancer. Nutrients 11(12): pii: E2989, 2019. PMID: 31817718. DOI: 10.3390/nu11122989

48 Hassan FU, Rehman MS, Khan MS, Ali MA, Javed A, Nawaz A and Yang C: Curcumin as an alternative epigenetic modulator: Mechanism of action and potential effects. Front Genet 10: 514 , 2019. PMID: 31214247. DOI: 10.3389/fgene.2019.00514

49 Hatami M, Abdolahi M, Soveyd N, Djalali M, Togha M and Honarvar NM: Molecular mechanisms of curcumin in neuroinflammatory disorders: A mini review of current evidences. Endocr Metab Immune Disord Drug Targets 19(3): 247-258, 2019. PMID: 30488803. DOI: 10.2174/1871530319666181129103056

50 Boyanapalli SS, Kong AT. "Curcumin, the King of Spices": Epigenetic regulatory mechanisms in the prevention of cancer, neurological, and inflammatory diseases. Curr Pharmacol Rep 1(2): 129-139, 2015. PMID: 26457241.

51 Costa-Pinheiro P, Montezuma D, Henrique R, Jerónimo C: Diagnostic and prognostic epigenetic biomarkers in cancer. Epigenomics 7(6): 1003-1015, 2015. PMID: 26479312. DOI: 10.2217/epi.15.56

52 Teiten $\mathrm{MH}$, Dicato $\mathrm{M}$ and Diederich $\mathrm{M}$ : Curcumin as a regulator of epigenetic events. Mol Nutr Food Res 57(9): 16191629, 2013. PMID: 23754571. DOI: 10.1002/mnfr.201300201

53 Liu W, Huang M, Zou Q and Lin W: Curcumin suppresses gastric cancer biological activity by regulation of miRNA-21: An in vitro study. Int J Clin Exp Pathol 11(12): 5820-5829, 2018. PMID: 31949668.

54 Gallardo M, Kemmerling U, Aguayo F, Bleak TC, Muñoz JP and Calaf GM: Curcumin rescues breast cells from epithelialmesenchymal transition and invasion induced by anti-miR-34a. Int J Oncol 56(2): 480-493, 2020. PMID: 31894298. DOI: 10.3892/ijo.2019.4939

55 Pickich MB, Hargrove MW, Phillips CN, Healy JC, Moore AN, Roberts MD and Martin JS: Effect of curcumin supplementation on serum expression of select cytokines and chemokines in a female rat model of nonalcoholic steatohepatitis. BMC Res Notes
12(1): 496, 2019. PMID: 31399137. DOI: 10.1186/s13104-0194540-5

56 Gouda MM and Bhandary YP: Curcumin down-regulates IL17A mediated p53-fibrinolytic system in bleomycin induced acute lung injury in vivo. J Cell Biochem 119(9): 7285-7299, 2018. PMID: 29775223. DOI: 10.1002/jcb.27026

57 Qin L, Qin J, Zhen X, Yang Q and Huang L: Curcumin protects against hepatic stellate cells activation and migration by inhibiting the CXCL12/CXCR4 biological axis in liver fibrosis: A study in vitro and in vivo. Biomed Pharmacother 101: 599-607, 2018. PMID: 29518606. DOI: 10.1016/j.biopha.2018.02.091

58 Calibasi-Kocal G, Pakdemirli A, Bayrak S, Ozupek NM, Sever T, Basbinar Y, Ellidokuz $\mathrm{H}$ and Yigitbasi T: Curcumin effects on cell proliferation, angiogenesis and metastasis in colorectal cancer. J BUON 24(4): 1482-1487, 2019. PMID: 31646795.

59 Zhang C, Hao Y, Wu L, Dong X, Jiang N, Cong B, Liu J, Zhang W, Tang D, De Perrot M and Zhao X: Curcumin induces apoptosis and inhibits angiogenesis in murine malignant mesothelioma. Int J Oncol 53(6): 2531-2541, 2018. PMID: 30272283. DOI: $10.3892 /$ ijo.2018.4569

60 Ouyang M, Luo Z, Zhang W, Zhu D, Lu Y, Wu J and Yao X: Protective effect of curcumin against irinotecan induced intestinal mucosal injury via attenuation of $\mathrm{NF} \mathrm{kB}$ activation, oxidative stress and endoplasmic reticulum stress. Int J Oncol 54(4): 13761386, 2019. PMID: 30968152. DOI: 10.3892/ijo.2019.4714

61 Tomeh MA, Hadianamrei R and Zhao X: A review of curcumin and its derivatives as anticancer agents. Int J Mol Sci 20(5) pii: E1033, 2019. PMID: 30818786. DOI: 10.3390/ijms20051033

62 Wei Y, Yang P, Cao S and Zhao L: The combination of curcumin and 5-fluorouracil in cancer therapy. Arch Pharm Res 41(1): 1-13, 2018. PMID: 29230689. DOI: 10.1007/s12272017-0979-x

63 Ko EY and Moon A: Natural products for chemoprevention of breast cancer. J Cancer Prev 20(4): 223-231, 2015. PMID: 26734584. DOI: 10.15430/JCP.2015.20.4.223

64 Grill AE, Shahani K, Koniar B and Panyam J: Chemopreventative efficacy of curcumin-loaded PLGA microparticles in a transgenic mouse model of HER-2-positive breast cancer. Drug Deliv Transl Res 8(2): 329-341, 2018. PMID: 28417445. DOI: 10.1007/s13346-017-0377-4

65 Shaito A, Posadino AM, Younes N, Hasan H, Halabi S, Alhababi D, Al-Mohannadi A, Abdel-Rahman WM, Eid AH, Nasrallah GK and Pintus G: Potential adverse effects of resveratrol: A literature review. Int J Mol Sci 21(6). pii: E2084, 2020. PMID: 32197410. DOI: 10.3390/ijms21062084

66 Meng X, Zhou J, Zhao CN, Gan RY and Li HB: Health benefits and molecular mechanisms of resveratrol: A narrative review. Foods 9(3): pii: E340, 2020. PMID: 32183376. DOI: 10.3390/foods 9030340

67 Ko JH, Sethi G, Um JY, Shanmugam MK, Arfuso F, Kumar AP, Bishayee A and Ahn KS: The role of resveratrol in cancer therapy. Int J Mol Sci 18(12): pii: E2589, 2017. PMID: 29194365. DOI: $10.3390 /$ ijms 18122589

68 Elshaer M, Chen Y, Wang XJ and Tang X: Resveratrol: An overview of its anti-cancer mechanisms. Life Sci 207: 340-349, 2018. DOI: $10.1016 /$ j.lfs. 2018.06 .028

69 Huminiecki L, Horbańczuk J: The functional genomic studies of resveratrol in respect to its anticancer effects. Biotechnol Adv 36(6): 1699-1708, 2018. PMID: 29476886. DOI: $10.1016 /$ j.biotechadv.2018.02.011 
70 Fernandes GFS, Silva GDB, Pavan AR, Chiba DE, Chin CM and Dos Santos JL: Epigenetic regulatory mechanisms induced by resveratrol. Nutrients 9(11): pii: E1201, 2017. PMID: 29104258. DOI: 10.3390/nu9111201

71 Sinha D, Sarkar N, Biswas J and Bishayee A: Resveratrol for breast cancer prevention and therapy: Preclinical evidence and molecular mechanisms. Semin Cancer Biol 40-41: 209-232, 2016. PMID: 26774195. DOI: 10.1016/j.semcancer.2015.11.001

72 Lubecka K, Kurzava L, Flower K, Buvala H, Zhang H, Teegarden D, Camarillo I, Suderman M, Kuang S, Andrisani O, Flanagan JM and Stefanska B: Stilbenoids remodel the DNA methylation patterns in breast cancer cells and inhibit oncogenic NOTCH signaling through epigenetic regulation of MAML2 transcriptional activity. Carcinogenesis 37(7): 656-668, 2016. PMID: 27207652. DOI: 10.1093/carcin/bgw048

73 Selvakumar P, Badgeley A, Murphy P, Anwar H, Sharma U, Lawrence $\mathrm{K}$ and Lakshmikuttyamma A: Flavonoids and other polyphenols act as epigenetic modifiers in breast cancer. Nutrients 12(3): pii: E761, 2020. DOI: 10.3390/nu12030761

74 Orsini F, Verotta L, Klimo K, Gerhäuser C: Synthesis of resveratrol derivatives and in vitro screening for potential cancer chemopreventative activities. Arch Pharm 349(6): 414427, 2016. PMID: 27159630. DOI: 10.1002/ardp.201600022

75 Verheul MJ, Slimestad R, Tjøstheim IH: From the producer to the consumer: greenhouse quality of the tomato influenced by the variety, maturity phase at the harvest, transport conditions and storage of the supermarket. J Agric Food Chem 63(20): 5026-5034, 2015. PMID: 25.916.229. DOI: 10.1021/jf505450j

76 Dono G, Rambla JL, Frusciante S, Granell A, Diretto G and Mazzucato A: Color mutations alter the biochemical composition in the San Marzano tomato fruit. Metabolites 10(3): pii: E110, 2020. PMID: 32183449. DOI: 10.3390/metabo10030110

77 D'Evoli L, Lombardi-Boccia G and Lucarini M: Influence of heat treatments on carotenoid content of cherry tomatoes. Foods 2(3): 352-363, 2013. PMID: 28239121. DOI: 10.3390/foods 2030352

78 Trejo-Solís C, Pedraza-Chaverrí J, Torres-Ramos M, JiménezFarfán D, Cruz Salgado A, Serrano-García N, Osorio-Rico L and Sotelo J: Multiple molecular and cellular mechanisms of action of lycopene in cancer inhibition. Evid Based Complement Alternat 2013: 705121, 2013. PMID: 23970935. DOI: $10.1155 / 2013 / 705121$

79 Ascenso A, Ribeiro H, Marques HC, Oliveira H, Santos C and Simões S: Chemoprevention of phytocarcinogenesis by lycopene. Exp Dermatol 23(12): 874-878, 2014. PMID: 25040310. DOI: $10.1111 /$ exd.12491

80 Heber D and Lu QY: Overview of mechanisms of action of lycopene. Exp Biol Med 227(10): 920-923, 2002. PMID: 12424335 .

81 Arathi BP, Sowmya PR, Kuriakose GC, Vijay K, Baskaran V, Jayabaskaran $\mathrm{C}$ and Lakshminarayana R: Enhanced cytotoxic and apoptosis inducing activity of lycopene oxidation products in different cancer cell lines. Food Chem Toxicol 97: 265-276, 2016. PMID: 27637924. DOI: 10.1016/ j.fct.2016.09.016

82 Guil-Guerrero JL, Ramos-Bueno R, Rodríguez-García I and López-Sánchez C: Cytotoxicity screening of several tomato extracts. J Med Food 14(1-2): 40-45, 2011. PMID: 21138360. DOI: $10.1089 /$ jmf.2010.0051

83 Chen J, O'Donoghue A, Deng YF, Zhang B, Kent F and O'Hare $\mathrm{T}$ : The effect of lycopene on the PI3K/AKT signalling pathway in prostate cancer. Anticancer Agents Med Chem 14(6): 800805, 2014. PMID: 24851879.

84 Li D, Chen L, Zhao W, Hao J and An R: MicroRNA-let-7f-1 is induced by lycopene and inhibits cell proliferation and triggers apoptosis in prostate cancer. Mol Med Rep 13(3): 2708-2714, 2016. PMID: 26847233. DOI: 10.3892/mmr.2016.4841

85 Usta C, Ozdemir S, Schiariti M and Puddu PE: The pharmacological use of ellagic acid-rich pomegranate fruit. Int J Food Sci Nutr 64(7): 907-913, 2013. PMID: 23700985. DOI: $10.3109 / 09637486.2013 .798268$

86 Kowshik J, Giri H, Kishore TK, Kesavan R, Vankudavath RN, Reddy GB, Dixit $M$ and Nagini $S$ : Ellagic acid inhibits VEGF/VEGFR2, PI3K/AKT and MAPK signaling cascades in the hamster cheek pouch carcinogenesis model. Anticancer Agents Med Chem 14(9): 1249-1260, 2014. PMID: 25060902.

87 Wang N, Wang ZY, Mo SL, Loo TY, Wang DM, Luo HB, Yang DP, Chen YL, Shen JG and Chen JP: Ellagic acid, a phenolic compound, exerts anti-angiogenesis effects via VEGFR-2 signaling pathway in breast cancer. Breast Cancer Res Treat 134(3): 943955, 2012. PMID: 22350787. DOI: 10.1007/s10549-012-1977-9

88 Ceci C, Lacal PM, Tentori L, De Martino MG, Miano R and Graziani G: Experimental evidence of the antitumor, antimetastatic and antiangiogenic activity of ellagic acid. Nutrients 10(11): pii: E1756, 2018. PMID: 30441769. DOI: 10.3390/nu10111756

89 Lernoux M, Schnekenburger M, Dicato M and Diederich M: Anti-cancer effects of naturally derived compounds targeting histone deacetylase 6-related pathways. Pharmacol Res 129: 337356, 2018. PMID: 29133216. DOI: 10.1016/j.phrs.2017.11.004

90 Lembo S, Balato A, Di Caprio R, Cirillo T, Giannini V, Gasparri F and Monfrecola G: The modulatory effect of ellagic acid and rosmarinic acid on ultraviolet-B-induced cytokine/ chemokine gene expression in skin keratinocyte (HaCaT) cells. Biomed Res Int 2014: 346793, 2014. PMID: 25162011. DOI: $10.1155 / 2014 / 346793$

91 Kumar D, Basu S, Parija L, Rout D, Manna S, Dandapat J and Debata PR: Curcumin and ellagic acid synergistically induce ROS generation, DNA damage, p53 accumulation and apoptosis in HeLa cervical carcinoma cells. Biomed Pharmacother 81: 3137, 2016. PMID: 27261574. DOI: 10.1016/j.biopha.2016.03.037

92 Legartová S, Sbardella G, Kozubek S, Bártová E: Ellagic acidchanged epigenome of ribosomal genes and condensed RPA194-positive regions of nucleoli in tumour cells. Folia Biol 61(2): 49-59, 2015. PMID: 26333121.

93 Kang I, Okla M and Chung S: Ellagic acid inhibits adipocyte differentiation through coactivator-associated arginine methyltransferase 1-mediated chromatin modification. J Nutr Biochem 25(9): 946-953, 2014. PMID: 24929439. DOI: 10.1016/j.jnutbio.2014.04.008

94 Rogan EG: The natural chemopreventative compound indole3-carbinol: State of the science. In Vivo 20(2): 221-228, 2006. PMID: 16634522.

95 Sivapalan T, Melchini A, Saha S, Needs PW, Traka MH, Tapp H, Dainty JR and Mithen RF: Bioavailability of glucoraphanin and sulforaphane from high-glucoraphanin broccoli. Mol Nutr Food Res 62(18): e1700911, 2018. PMID: 29266773. DOI: $10.1002 / \mathrm{mnfr} .201700911$

96 Fahey JW, Holtzclaw WD, Wehage SL, Wade KL, Stephenson KK and Talalay P: Sulforaphane bioavailability from glucoraphanin-rich broccoli: control by active endogenous 
myrosinase. PLoS One 10(11): e0140963, 2015. PMID: 26524341. DOI: 10.1371/journal.pone.0140963

97 Okunade O, Niranjan K, Ghawi SK, Kuhnle G and Methven L: Supplementation of the diet by exogenous myrosinase via mustard seeds to increase the bioavailability of sulforaphane in healthy human subjects after the consumption of cooked broccoli. Mol Nutr Food Res 62(18): e1700980, 2018. PMID: 29806738. DOI: $10.1002 / \mathrm{mnfr} .201700980$

98 Aggarwal BB and Ichikawa H: Molecular targets and anticancer potential of indole-3-carbinol and its derivatives. Cell Cycle 4(9): 1201-1215, 2005. PMID: 16082211.

99 Reed GA, Arneson DW, Putnam WC, Smith HJ, Gray JC, Sullivan DK, Mayo MS, Crowell JA and Hurwitz A: Singledose and multiple-dose administration of indole-3-carbinol to women: Pharmacokinetics based on 3,3'-diindolylmethane. Cancer Epidemiol Biomarkers Prev 15(12): 2477-2481, 2006. PMID: 17164373. DOI: 10.1158/1055-9965.EPI-06-0396

100 Arslan AA, Koenig KL, Lenner P, Afanasyeva Y, Shore RE, Chen Y, Lundin E, Toniolo P, Hallmans G and ZeleniuchJacquotte A: Circulating estrogen metabolites and risk of breast cancer in postmenopausal women. Cancer Epidemiol Biomarkers Prev 23(7): 1290-1297, 2014. PMID: 24769889. DOI: 10.1158/1055-9965.EPI-14-0009

101 Zeleniuch-Jacquotte A, Shore RE, Afanasyeva Y, Lukanova A, Sieri S, Koenig KL, Idahl A, Krogh V, Liu M, Ohlson N, Muti P, Arslan AA, Lenner P, Berrino F, Hallmans G, Toniolo P and Lundin E: Postmenopausal circulating levels of 2- and $16 \alpha-$ hydroxyestrone and risk of endometrial cancer. $\mathrm{Br} \mathrm{J}$ Cancer 105(9): 1458-1464, 2011. PMID: 21952628. DOI: 10.1038/ bjc. 2011.381

102 Ziegler RG, Fuhrman BJ, Moore SC and Matthews CE: Epidemiologic studies of estrogen metabolism and breast cancer. Steroids Ju 99(PtA): 67-75, 2015. PMID: 25725255. DOI: $10.1016 /$ j.steroids.2015.02.015

103 Lee SU, Rhee Mc, Min YK and Kim SH: Involvement of peroxiredoxin IV in the 16alpha-hydroxyestrone-induced proliferation of human MCF-7 breast cancer cells. Cell Biol Int 32(4): 401-405, 2008. PMID: 18272409. DOI: 10.1016/j.cellbi. 2007.12.009

104 Falk RT, Brinton LA, Dorgan JF, Fuhrman BJ, Veenstra TD, Xu $X$ and Gierach GL: Relationship of serum estrogens and estrogen metabolites to postmenopausal breast cancer risk: A nested case-control study. Breast Cancer Res 15(2): R34, 2013. PMID: 23607871. DOI: 10.1186/bcr3416

105 Firestone GL and Sundar SN: Minireview: modulation of hormone receptor signaling by dietary anticancer indoles. Mol Endocrinol 23(12): 1940-1947, 2009. PMID: 19837944. DOI: 10.1210/me.2009-0149

106 Le HT, Schaldach CM, Firestone GL and Bjeldanes LF: Plantderived 3,3'-Diindolylmethane is a strong androgen antagonist in human prostate cancer cells. J Biol Chem 278(23): 2113621145, 2003. PMID: 12665522.

107 Hodges RE and Minich DM: Modulation of metabolic detoxification pathways using foods and food-derived components: A scientific review with clinical application. J Nutr Metab 2015: 760689, 2015. PMID: 26167297. DOI: $10.1155 / 2015 / 760689$

108 Sepkovic DW, Raucci L, Stein J, Carlisle AD, Auborn K, Ksieski HB, Nyirenda $\mathrm{T}$ and Bradlow HL: 3,3'Diindolylmethane increases serum interferon- $\gamma$ levels in the
K14-HPV16 transgenic mouse model for cervical cancer. In Vivo 26(2): 207-211, 2012. PMID: 22351660.

109 Jin L and Xu ZX: Recent advances in the study of HPVassociated carcinogenesis. Virol Sin 30(2): 101-106, 2015. PMID: 25910482. DOI: 10.1007/s12250-015-3586-3

110 Chen J: Signaling pathways in HPV-associated cancers and therapeutic implications. Rev Med Virol 25(Suppl 1): 24-53, 2015. PMID: 25752815. DOI: $10.1002 / \mathrm{rmv} .1823$

111 Kaufman-Szymczyk A, Majewski G, Lubecka-Pietruszewska K and Fabianowska-Majewska K: The role of sulforaphane in epigenetic mechanisms, including interdependence between histone modification and DNA methylation. Int J Mol Sci 16(12): 29732-29743, 2015. PMID: 26703571. DOI: $10.3390 /$ ijms 161226195

112 Su X, Jiang X, Meng L, Dong X, Shen Y and Xin Y: Anticancer activity of sulforaphane: The epigenetic mechanisms and the NRF2 signaling pathway. Oxid Med Cell Longev 2018: 5438179, 2018. PMID: 29977456. DOI: 10.1155/2018/5438179

113 Zhang C, Su ZY, Khor TO, Shu L and Kong AN: Sulforaphane enhances NRF2 expression in prostate cancer TRAMP C1 cells through epigenetic regulation. Biochem Pharmacol 85(9): 13981404, 2013. PMID: 23416117. DOI: 10.1016/j.bcp.2013.02.010

114 Singh KB, Hahm ER, Alumkal JJ, Foley LM, Hitchens TK, Shiva SS, Parikh RA, Jacobs BL and Singh SV: Reversal of the Warburg phenomenon in chemoprevention of prostate cancer by sulforaphane. Carcinogenesis 40(12): 1545-1556, 2019. PMID: 31555797. DOI: 10.1093/carcin/bgz155

115 Royston KJ, Paul B, Nozell S, Rajbhandari R and Tollefsbol TO: Withaferin A and sulforaphane regulate breast cancer cell cycle progression through epigenetic mechanisms. Exp Cell Res 368(1): 67-74, 2018. PMID: 29689276. DOI: 10.1016/j.yexcr.2018.04.015

116 Yang F, Wang F, Liu Y, Wang S, Li X, Huang Y, Xia Y and Cao C: Sulforaphane induces autophagy by inhibition of HDAC6mediated PTEN activation in triple-negative breast cancer cells. Life Sci 213: 149-157, 2018. PMID: 30352240. DOI: 10.1016/j.lfs.2018.10.034

117 Cao C, Wu H, Vasilatos SN, Chandran U, Qin Y, Wan Y, Oesterreich S, Davidson NE and Huang Y: HDAC5-LSD1 axis regulates antineoplastic effect of natural HDAC inhibitor sulforaphane in human breast cancer cells. Int J Cancer 143(6): 1388-1401, 2018. PMID: 29633255. DOI: 10.1002/ijc.31419

118 Soundararajan P and Kim JS: Anti-carcinogenic glucosinolates in cruciferous vegetables and their antagonistic effects on prevention of cancers. Molecules Nov 23(11): pii: E2983, 2018. PMID: 30445746. DOI: 10.3390/molecules23112983

119 Martin SL, Kala R and Tollefsbol TO: Mechanisms for the inhibition of colon cancer cells by sulforaphane through epigenetic modulation of microRNA-21 and human telomerase reverse transcriptase (hTERT) down-regulation. Curr Cancer Drug Targets 18(1): 97-106, 2018. PMID: 28176652. DOI: $10.2174 / 1568009617666170206104032$

120 Meeran SM, Patel SN and Tollefsbol TO: Sulforaphane causes epigenetic repression of hTERT expression in human breast cancer cell lines. PLoS One 5(7): e11457, 2010. PMID: 20625516. DOI: 10.1371/journal.pone.0011457

121 Bayat Mokhtari R, Baluch N, Homayouni TS, Morgatskaya E, Kumar S, Kazemi P and Yeger H: The role of sulforaphane in cancer chemoprevention and health benefits: a mini-review. J Cell Commun Signal 12(1): 91-101, 2018. PMID: 28735362. DOI: $10.1007 / \mathrm{s} 12079-017-0401-y$ 
122 Jiang X, Liu Y, Ma L, Ji R, Qu Y, Xin Y and Lv G: Chemopreventative activity of sulforaphane. Drug Des Devel Ther 12: 2905-2913, 2018. PMID: 30254420. DOI: 10.2147/DDDT.S100534

123 Kotsopoulos J, Zhang S, Akbari M, Salmena L, Llacuachaqui M, Zeligs M, Sun P and Narod SA: BRCA1 mRNA levels following a 4-6-week intervention with oral 3,3'-diindolylmethane. Br J Cancer 111(7): 1274, 2014. PMID: 25025957. DOI: 10.1038/bjc.2014.391

124 Pastushenko I and Blanpain C: EMT transition states during tumor progression and metastasis. Trends Cell Biol 29(3): 212226, 2019. PMID: 30594349. DOI: 10.1016/j.tcb.2018.12.001

125 Lee GA, Hwang KA and Choi KC: Roles of dietary phytoestrogens on the regulation of epithelial4mesenchymal transition in diverse cancer metastasis. Toxins 8(6): pii: E162, 2016. PMID: 27231938. DOI: $10.3390 /$ toxins 8060162

126 Fang D and Kitamura H: Cancer stem cells and epithelialmesenchymal transition in urothelial carcinoma: Possible pathways and potential therapeutic approaches. Int J Urol 25(1): 7-17, 2018. PMID: 28697535. DOI: 10.1111/iju.13404

127 Katz E, Nisani S and Chamovitz DA: Indole-3-carbinol: A plant hormone combatting cancer. F1000Res, 2018. PMID: 29904587. DOI: 10.12688/f1000research.14127.1

128 Fujioka N, Fritz V, Upadhyaya P, Kassie F and Hecht SS: Research on cruciferous vegetables, indole-3-carbinol, and cancer prevention: A tribute to Lee W. Wattenberg. Mol Nutr Food Res 60(6): 1228-1238, 2016. PMID: 26840393. DOI:10.1002/mnfr.201500889

129 Priyadarshini A, Rajauria G, O'Donnell CP and Tiwari BK: Emerging food processing technologies and factors impacting their industrial adoption. Crit Rev Food Sci Nutr 59(19): 3082-3101, 2019. PMID: 29863891. DOI: 10.1080/10408398.2018.1483890

130 Royston KJ and Tollefsbol TO: The epigenetic impact of cruciferous vegetables on cancer prevention. Curr Pharmacol Rep 1(1): 46-51, 2015. PMID: 25774338.

131 Tajmohammadi A, Razavi BM and Hosseinzadeh H: Silybum marianum (milk thistle) and its main constituent, silymarin, as a potential therapeutic plant in metabolic syndrome: A review. Phytother Res 32(10): 1933-1949, 2018. PMID: 30015401. DOI: $10.1002 /$ ptr.6153

132 Samu Z, Nyiredy S, Baitz-Gács E, Varga Z, Kurtán T, Dinya Z and Antus S: Structure elucidation and antioxidant activity of (-)-isosilandrin isolated from Silybum marianum L: Chem Biodivers 1(11): 1668-1677, 2004. PMID: 17191807.

133 Surai PF: Silymarin as a natural antioxidant: an overview of the current evidence and perspectives. Antioxidants 4(1): 204-247, 2015. PMID: 26785346. DOI: 10.3390/antiox4010204

134 Pourová J, Applová L, Macáková K, Vopršalová M, Migkos T, Bentanachs R, Biedermann D, Petrásková L, Tvrdý V, Hrubša M, Karlíčková J, Křen V, Valentová K and Mladěnka $\mathrm{P}$ : The effect of silymarin flavonolignans and their sulfated conjugates on platelet aggregation and blood vessels ex vivo. Nutrients 11(10): pii: E2286, 2019. PMID: 31554252. DOI: $10.3390 /$ nu 11102286

135 Karimi G, Vahabzadeh M, Lari P, Rashedinia M and Moshiri M: "Silymarin", a promising pharmacological agent for treatment of diseases. Iran J Basic Med Sci 14(4): 308-317, 2011. PMID: 23492971.

136 Panche AN, Diwan AD and Chandra SR: Flavonoids: An overview. J Nutr Sci 5: e47, 2016. PMID: 28620474. DOI: $10.1017 /$ jns.2016.41
137 Abenavoli L, Capasso R, Milic N and Capasso F: Milk thistle in liver diseases: past, present, future. Phytother Res 24(10): 1423-1432, 2010. PMID: 20564545. DOI: 10.1002/ptr.3207

138 Zhang C, Wang K, Yang L, Liu R, Chu Y, Qin X, Yang P and $\mathrm{Yu} \mathrm{H}$ : Lipid metabolism in inflammation-related diseases. Analyst 143(19): 4526-4536, 2018. PMID: 30128447. DOI: $10.1039 / \mathrm{c} 8 \mathrm{an} 01046 \mathrm{c}$

139 Csupor D, Csorba A and Hohmann J: Recent advances in the analysis of flavonolignans of Silybum marianum. J Pharm Biomed Anal 130: 301-317, 2016. PMID: 27321822. DOI: 10.1016/j.jpba.2016.05.034

140 Basiglio CL, Sánchez Pozzi EJ, Mottino AD and Roma MG: Differential effects of silymarin and its active component silibinin on plasma membrane stability and hepatocellular lysis. Chem Biol Interact 179(2-3): 297-303, 2009. PMID: 19135039. DOI: $10.1016 /$ j.cbi.2008.12.008

141 Anestopoulos I, Sfakianos AP, Franco R, Chlichlia K, Panayiotidis MI, Kroll DJ and Pappa A: A novel role of silibinin as a putative epigenetic modulator in human prostate carcinoma. Molecules 22(1): pii: E62, 2016. PMID: 28042859. DOI: $10.3390 /$ molecules22010062

142 Barros TMB, Lima APB, Almeida TC and da Silva GN: Inhibition of urinary bladder cancer cell proliferation by silibinin. Environ Mol Mutagen, 2020. PMID: 32078183. DOI: 10.1002/em.22363

143 Mateen S, Raina K and Agarwal R: Chemopreventative and anti-cancer efficacy of silibinin against growth and progression of lung cancer. Nutr Cancer 65(S1): 3-11, 2013. PMID: 23682778. DOI: $10.1080 / 01635581.2013 .785004$

144 Kauntz H, Bousserouel S, Gossé F and Raul F: Epigenetic effects of the natural flavonolignan silibinin on colon adenocarcinoma cells and their derived metastatic cells. Oncol Lett 5(4): 1273-1277, 2013. PMID: 23599778.

145 Ramasamy K and Agarwal R: Multitargeted therapy of cancer by silymarin. Cancer Lett 269(2): 352-362, 2008. PMID: 18472213. DOI: 10.1016/j.canlet.2008.03.053

146 Morris J, Fang Y, De Mukhopdhyay K and Wargovich MJ: Natural agents used in chemoprevention of aerodigestive and GI cancers. Curr Pharmacol Rep 2(1): 11-20, 2016. PMID: 27134816.

147 Antonious GF, Berke T and Jarret RL: Pungency in Capsicum chinense: Variation among countries of origin. J Environ Sci Health B 44(2): 179-184, 2009. PMID: 19130376. DOI: $10.1080 / 10934520802539830$

148 Wahyuni Y, Ballester AR, Sudarmonowati E, Bino RJ and Bovy AG: Secondary metabolites of Capsicum species and their importance in the human diet. J Nat Prod 76(4): 783-793, 2013. PMID: 23477482. DOI: $10.1021 / \mathrm{np} 300898 \mathrm{z}$

149 Scheau C, Badarau IA, Caruntu C, Mihai GL, Didilescu AC, Constantin C and Neagu M: Capsaicin: Effects on the pathogenesis of hepatocellular carcinoma. Molecules 24(13): pii: E2350, 2019. PMID: 31247901. DOI: 10.3390/molecules24132350

150 Parveen A, Subedi L, Kim HW, Khan Z, Zahra Z, Farooqi MQ and Kim SY: Phytochemicals Targeting VEGF and VEGFrelated multifactors as anticancer therapy. J Clin Med 8(3): pii: E350, 2019. PMID: 30871059. DOI: $10.3390 /$ jcm8030350

151 Chen HY, Lee YH, Chen HY, Yeh CA, Chueh PJ and Lin YM: Capsaicin inhibited aggressive phenotypes through downregulation of tumor-associated NADH oxidase (tNOX) by POU domain transcription factor POU3F2. Molecules 21(6): pii: E733, 2016. PMID: 27271588. DOI: 10.3390/molecules21060733 
152 Zheng L, Chen J, Ma Z, Liu W, Yang F, Yang Z, Wang K, Wang $\mathrm{X}, \mathrm{He} \mathrm{D}$ and Li L: Capsaicin causes inactivation and degradation of the androgen receptor by inducing the restoration of miR-449a in prostate cancer. Oncol Rep 34(2): 1027-1034, 2015. PMID: 26081756. DOI: 10.3892/or.2015.4055

153 Yang MH, Jung SH, Sethi G and Ahn KS: Pleiotropic pharmacological actions of capsazepine, a synthetic analogue of capsaicin, against various cancers and inflammatory diseases. Molecules 24(5): pii: E995, 2019. PMID: 30871017. DOI: 10.3390/molecules24050995

154 Zhu M, Yu X, Zheng Z, Huang J, Yang X and Shi H: Capsaicin suppressed activity of prostate cancer stem cells by inhibition of Wnt/ $\beta$-catenin pathway. Phytother Res, 2019. PMID: 31782192. DOI: $10.1002 /$ ptr.6563

155 Kumar S and Pandey AK: Chemistry and biological activities of flavonoids: an overview. Sci World J 2013: 162750, 2013. PMID: 24470791. DOI: 10.1155/2013/162750

156 Anand David AV, Arulmoli R and Parasuraman S: Overviews of biological importance of quercetin: A bioactive flavonoid. Pharmacogn Rev 10(20): 84-89, 2016. PMCID: 28082789. DOI: $10.4103 / 0973-7847.194044$

157 Ilahy R, Tlili I, Siddiqui MW, Hdider C and Lenucci MS: Inside and beyond color: Comparative overview of functional quality of tomato and watermelon fruits. Front Plant Sci 10: 769, 2019. PMID: 31263475. DOI: 10.3389/fpls.2019.00769

158 Chen S, Jiang H, Wu X and Fang J: Therapeutic effects of quercetin on inflammation, obesity, and type 2 diabetes. Mediators Inflamm 2016: 9340637, 2016. PMID: 28003714. DOI: $10.1155 / 2016 / 9340637$

159 Luo CL, Liu YQ, Wang P, Song CH, Wang KJ, Dai LP, Zhang JY and $\mathrm{Ye} \mathrm{H}$ : The effect of quercetin nanoparticle on cervical cancer progression by inducing apoptosis, autophagy and anti-proliferation via JAK2 suppression. Biomed Pharmacother 82: 595-605, 2016. PMID: 27470402. DOI: 10.1016/j.biopha.2016.05.029

160 Wright B, Gibson T, Spencer J, Lovegrove JA and Gibbins JM: Platelet-mediated metabolism of the common dietary flavonoid, quercetin. PLoS One 5(3): e9673, 2010. PMID: 20300638. DOI: 10.1371/journal.pone.0009673

161 Kwak JH, Seo JM, Kim NH, Arasu MV, Kim S, Yoon MK and Kim SJ: Variation of quercetin glycoside derivatives in three onion (Allium cepa L.) varieties. Saudi J Biol Sci 24(6): 1387-1391, 2017. PMID: 28855836. DOI: 10.1016/j.sjbs.2016.05.014

162 Kaushik D, O'Fallon K, Clarkson PM, Dunne CP, Conca KR and Michniak-Kohn B: Comparison of quercetin pharmacokinetics following oral supplementation in humans. J Food Sci 77(11): H231-238, 2012. PMID: 23094941. DOI: 10.1111/j.1750-3841.2012.02934.x

163 García-Mediavilla V, Crespo I, Collado PS, Esteller A, Sánchez-Campos S, Tuñón MJ and González-Gallego J: The anti-inflammatory flavones quercetin and kaempferol cause inhibition of inducible nitric oxide synthase, cyclooxygenase- 2 and C-reactive protein, and down-regulation of the nuclear factor kappaB pathway in Chang Liver cells. Eur J Pharmacol 557(2-3): 221-229, 2007. PMID: 17184768.

164 Ruiz PA, Braune A, Hölzlwimmer G, Quintanilla-Fend L and Haller D: Quercetin inhibits TNF-induced NF-kappaB transcription factor recruitment to proinflammatory gene promoters in murine intestinal epithelial cells. J Nutr 137(5): 1208-1215, 2007. PMID: 17449583.
165 Shoskes DA and Nickel JC: Quercetin for chronic prostatitis/chronic pelvic pain syndrome. Urol Clin North Am 38(3): 279-284, 2011. PMID: 21798389. DOI: 10.1016/j.ucl.2011.05.003

166 Marcoccia D, Pellegrini M, Fiocchetti M, Lorenzetti S and Marino M: Food components and contaminants as (anti)androgenic molecules. Genes Nutr 12: 6, 2017. PMID: 28239427. DOI: 10.1186/s12263-017-0555-5

167 Vijayababu MR, Arunkumar A, Kanagaraj P and Arunakaran J: Effects of quercetin on insulin-like growth factors (IGFs) and their binding protein-3 (IGFBP-3) secretion and induction of apoptosis in human prostate cancer cells. J Carcinog 5: 10, 2006. PMID: 16600019.

168 Rivera Rivera A, Castillo-Pichardo L, Gerena Y and Dharmawardhane S: Anti-breast cancer potential of quercetin via the AKT/AMPK/mammalian target of rapamycin (mTOR) signaling cascade. PLoS One 11(6): e0157251, 2016. PMID: 27285995. DOI: 10.1371/journal.pone.0157251

169 Cao L, Yang Y, Ye Z, Lin B, Zeng J, Li C, Liang T, Zhou K and Li J: Quercetin 3 methyl ether suppresses human breast cancer stem cell formation by inhibiting the Notch1 and PI3K/Akt signaling pathways. Int J Mol Med 42(3): 1625-1636, 2018. PMID: 29956731. DOI: 10.3892/ijmm.2018.3741

170 Niu G, Yin S, Xie S, Li Y, Nie D, Ma L, Wang X and Wu Y: Quercetin induces apoptosis by activating caspase-3 and regulating BCL-2 and cyclo-oxygenase- 2 pathways in human HL-60 cells. Acta Biochim Biophys Sin 43(1): 30-37, 2011. PMID: 21173056. DOI: 10.1093/abbs/gmq107

171 Ward AB, Mir H, Kapur N, Gales DN, Carriere PP and Singh $\mathrm{S}$ : Quercetin inhibits prostate cancer by attenuating cell survival and inhibiting anti-apoptotic pathways. World J Surg Oncol 16(1): 108, 2018. PMID: 29898731. DOI: 10.1186/s12957-018$1400-\mathrm{z}$

172 Russo GL, Russo M, Spagnuolo C, Tedesco I, Bilotto S, Iannitti $\mathrm{R}$ and Palumbo R: Quercetin: A pleiotropic kinase inhibitor against cancer. Cancer Treat Res 159: 185-205, 2014. PMID: 24114481. DOI: 10.1007/978-3-642-38007-5_11

173 Khan N, Syed DN, Ahmad N and Mukhtar H: Fisetin: A dietary antioxidant for health promotion. Antioxid Redox Signal 19(2): 151-162, 2013. PMID: 23121441. DOI: 10.1089/ars.2012.4901

174 Li J, Gong X, Jiang R, Lin D, Zhou T, Zhang A, Li H, Zhang $\mathrm{X}$, Wan J, Kuang G and Li H: Fisetin inhibited growth and metastasis of triple-negative breast cancer by reversing epithelial-to-mesenchymal transition via PTEN/AKT/GSK3 $\beta$ Signal Pathway. Front Pharmacol 9: 772, 2018. PMID: 30108501. DOI: 10.3389/fphar.2018.00772

$175 \mathrm{Li} \mathrm{Y,} \mathrm{Jia} \mathrm{S} \mathrm{and} \mathrm{Dai} \mathrm{W:} \mathrm{Fisetin} \mathrm{modulates} \mathrm{human} \mathrm{oral} \mathrm{squamous}$ cell carcinoma proliferation by blocking PAK4 signaling pathways. Drug Des Devel Ther 14: 773-782, 2020. PMID: 32158195. DOI: 10.2147/DDDT.S229270

176 Lall RK, Adhami VM and Mukhtar H: Dietary flavonoid fisetin for cancer prevention and treatment. Mol Nutr Food Res 60(6): 1396-1405, 2016. PMID: 27059089. DOI: 10.1002/mnfr. 201600025

177 Kashyap D, Sharma A, Sak K, Tuli HS, Buttar HS and Bishayee A: Fisetin: A bioactive phytochemical with potential for cancer prevention and pharmacotherapy. Life Sci 194: 7587, 2018. PMID: 29225112. DOI: 10.1016/j.lfs.2017.12.005

178 Syed DN, Adhami VM, Khan MI and Mukhtar H: Inhibition of AKT/mTOR signaling by the dietary flavonoid fisetin. Anticancer Agents Med Chem 13(7): 995-1001, 2013. PMID: 23293889. 
179 Zhang XJ and Jia SS: Fisetin inhibits laryngeal carcinoma through regulation of $\mathrm{AKT} / \mathrm{NF}-\mathrm{KB} / \mathrm{mTOR}$ and ERK1/2 signaling pathways. Biomed Pharmacother 83: 1164-1174, 2016. PMID: 27551764. DOI: 10.1016/j.biopha.2016.08.035

180 Singh BN, Shankar S and Srivastava RK: Green tea catechin, epigallocatechin-3-gallate (EGCG): Mechanisms, perspectives and clinical applications. Biochem Pharmacol 82(12): 18071821, 2011. PMID: 21827739. DOI: 10.1016/j.bcp.2011.07.093

181 Cione E, La Torre C, Cannataro R, Caroleo MC, Plastina P and Gallelli L: Quercetin, epigallocatechin gallate, curcumin, and resveratrol: from dietary sources to human microRNA modulation. Molecules 25(1): pii: E63, 2019. PMID: 31878082. DOI: $10.3390 /$ molecules 25010063

182 Yiannakopoulou EC: Targeting DNA methylation with green tea catechins. Pharmacology 95(3-4): 111-116, 2015. PMID: 25792496. DOI: $10.1159 / 000375503$

183 Shirakami Y, Shimizu M and Moriwaki H: Cancer chemoprevention with green tea catechins: From bench to bed. Curr Drug Targets 13(14): 1842-1857 2012. Review. PMID: 23140294.

184 Zhen MC, Huang XH, Wang Q, Sun K, Liu YJ, Li W, Zhang LJ, Cao LQ and Chen XL: Green tea polyphenol epigallocatechin3-gallate suppresses rat hepatic stellate cell invasion by inhibition of MMP-2 expression and its activation. Acta Pharmacol Sin 27(12): 1600-1607, 2006. PMID: 17112415.

185 Deb G, Shankar E, Thakur VS, Ponsky LE, Bodner DR, Fu P and Gupta S: Green tea-induced epigenetic reactivation of tissue inhibitor of matrix metalloproteinase-3 suppresses prostate cancer progression through histone-modifying enzymes. Mol Carcinog 58(7): 1194-1207, 2019. PMID: 30854739. DOI: $10.1002 / \mathrm{mc} .23003$

186 Khoo HE, Azlan A, Tang ST and Lim SM: Anthocyanidins and anthocyanins: colored pigments as food, pharmaceutical ingredients, and the potential health benefits. Food Nutr Res 61(1): 1361779, 2017. PMID: 28970777. DOI: 10.1080/16546 628.2017 .1361779

187 Key TJ: Fruit and vegetables and cancer risk. Br J Cancer 104(1): 6-11, 2011. PMID: 21119663. DOI: 10.1038/sj.bjc.6606032

188 Zubair H, Azim S, Ahmad A, Khan MA, Patel GK, Singh S and Singh AP: Cancer chemoprevention by phytochemicals: Nature's healing touch. Molecules 22(3): pii: E395, 2017. PMID: 28273819. DOI: 10.3390/molecules22030395

189 Baena Ruiz R, Salinas Hernández P: Cancer chemoprevention by dietary phytochemicals: Epidemiological evidence. Maturitas 94: 13-19, 2016. PMID: 27823732. DOI: 10.1016/j.maturitas.2016.08.004

190 Fimognari C, Lenzi M and Hrelia P: Chemoprevention of cancer by isothiocyanates and anthocyanins: mechanisms of action and structure-activity relationship. Curr Med Chem 15(5): 440-447, 2008. PMID: 18288999.

191 Ratovitski EA: Anticancer natural compounds as epigenetic modulators of gene expression. Curr Genomics 18(2): 175-205, 2017. PMID: 28367075. DOI: 10.2174/13892029176661608 03165229
192 Carlos-Reyes Á, López-González JS, Meneses-Flores M, GallardoRincón D, Ruíz-García E, Marchat LA, Astudillo-de la Vega H, Hernández de la Cruz ON and López-Camarillo C: Dietary compounds as epigenetic modulating agents in cancer. Front Genet 10: 79, 2019. PMID: 30881375. DOI: 10.3389/fgene.2019.00079

193 Veneziani G, Esposto S, Taticchi A, Urbani S, Selvaggini R, Di Maio I, Sordini B and Servili M: Cooling treatment of olive paste during the oil processing: Impact on the yield and extra virgin olive oil quality. Food Chem 221: 107-113, 2017. PMID: 27979061. DOI: 10.1016/j.foodchem.2016.10.067

194 Yubero-Serrano EM, Lopez-Moreno J, Gomez-Delgado F and Lopez-Miranda J: Extra virgin olive oil: More than a healthy fat. Eur J Clin Nutr 72(Suppl 1): 8-17, 2019. PMID: 30487558. DOI: $10.1038 / \mathrm{s} 41430-018-0304-\mathrm{x}$

195 Gaforio JJ, Visioli F, Alarcón-de-la-Lastra C, Castañer O, Delgado-Rodríguez M, Fitó M, Hernández AF, Huertas JR, Martínez-González MA, Menendez JA, Osada J, Papadaki A, Parrón T, Pereira JE, Rosillo MA, Sánchez-Quesada C, Schwingshackl L, Toledo E and Tsatsakis AM: Virgin Olive Oil and Health: Summary of the III International Conference on Virgin Olive Oil and Health Consensus Report, JAEN (Spain) 2018. Nutrients 11(9): pii: E2039, 2019. PMID: 31480506. DOI: $10.3390 /$ nu11092039

196 Dunaway S, Odin R, Zhou L, Ji L, Zhang Y and Kadekaro AL: Natural antioxidants: Multiple mechanisms to protect skin from solar radiation. Front Pharmacol 9: 392, 2018. PMID: 29740318. DOI: $10.3389 /$ fphar.2018.00392

197 Parkinson L and Keast R: Oleocanthal, a phenolic derived from virgin olive oil: a review of the beneficial effects on inflammatory disease. Int J Mol Sci 15(7): 12323-12334, 2014. PMID: 25019344. DOI: 10.3390/ijms 150712323

198 Menendez JA, Papadimitropoulou A, Vellon L and Lupu R: A genomic explanation connecting "Mediterranean diet", olive oil and cancer: Oleic acid, the main monounsaturated fatty acid of olive oil, induces formation of inhibitory "PEA3 transcription factor-PEA3 DNA binding site" complexes at the HER-2/neu (ERBB-2) oncogene promoter in breast, ovarian and stomach cancer cells. Eur J Cancer 42(15): 2425-2432, 2006. PMID: 16406575.

199 Menendez JA, Vazquez-Martin A, Colomer R, Brunet J, Carrasco-Pancorbo A, Garcia-Villalba R, Fernandez-Gutierrez A and Segura-Carretero A: Olive oil's bitter principle reverses acquired autoresistance to trastuzumab (Herceptin) in HER2overexpressing breast cancer cells. BMC Cancer 7: 80, 2007. PMID: 17490486.
Received April 6, 2020

Revised April 15, 2020

Accepted April 17, 2020 